\title{
Investment Behavior, Observable Expectations, and Internal Funds
}

\author{
Jason G. Cummins * \\ Assistant Professor \\ New York University \\ 269 Mercer Street \\ New York, NY 10003 \\ jcummins@econ.nyu.edu
}

\author{
Kevin A. Hassett \\ Resident Scholar \\ American Enterprise Institute \\ 115017 th Street NW \\ Washington, DC 20036 \\ khassett@aei.org
}

\author{
Stephen D. Oliner \\ Asst. Dir. of Research \\ Federal Reserve Board \\ Mail Stop 93 \\ Washington, DC 20551 \\ soliner@frb.gov
}

First Draft: September 8, 1997

Second Draft: July 6, 1998

Third Draft: March 31, 1999

\begin{abstract}
We use earnings forecasts from securities analysts to construct more accurate measures of the fundamentals that affect the expected returns to investment. We find that investment responds significantly - in both economic and statistical terms - to our new measures of fundamentals. Our estimates imply that the elasticity of the investmentcapital ratio with respect to a change in fundamentals is generally greater than unity. In addition, we find that internal funds are uncorrelated with investment spending, even for selected subsamples of firms - those paying no dividends and those without bond ratings - that have been found to be "liquidity constrained" in previous studies. Our results cast doubt on the evidence for liquidity constraints from the many studies that have used Tobin's $Q$ to control for the expected returns to investment.
\end{abstract}

JEL Classification: D92, E22.

Keywords: Investment; Tobin's Q; Cash Flow; Liquidity Constraints.

\footnotetext{
We thank Steve Bond, Ricardo Caballero, Mark Gertler, Simon Gilchrist, John Hand, Glenn Hubbard, Steve Kaplan, Owen Lamont, Plutarchos Sakellaris and seminar participants at Brandeis University, UC Berkeley, the Econometric Society Winter Meetings, the Federal Reserve Board, University College London, the University of Maryland, the NBER Economic Fluctuations and Monetary Economics Program Meetings, Northwestern University, New York University, Tilburg University, and Yale University for helpful comments and suggestions. Cummins gratefully acknowledges financial support from the C. V. Starr Center for Applied Economics. The views expressed in this paper are those of the authors, and do not reflect those of the Board of Governors of the Federal Reserve System or its staff. The data on earnings expectations are provided by $\mathrm{I} / \mathrm{B} / \mathrm{E} / \mathrm{S}$ International Inc.
}

* Presenting/Corresponding author. 


\section{Introduction}

Until recently, the consensus among researchers was that neoclassical fundamentals fail to explain the observed movements in business investment (see, e.g., Chirinko 1993). For example, in a well-known study, Summers (1981) found that a one percent increase in the shadow value of capital increases investment by a paltry 0.02 percent. Furthermore, models derived from neoclassical fundamentals have fared poorly in horseraces against ad hoc accelerator models of investment (see, e.g., Bernanke, Bohn, and Reiss 1988). This result could reflect the consequences of asymmetric information in financial markets: Lenders become more favorably inclined to make loans when a firm's net worth improves, leading to an expansion of business investment. In an important study, Fazzari et al. (1988) used firm-level panel data to try to isolate firms for which investment may be constrained by internal funds. They found that the firms most likely to face liquidity constraints tend to have the highest sensitivity of investment to cash flow. Subsequent empirical research has generally supported this finding. ${ }^{1}$

Although this literature suggests that neoclassical models of investment perform poorly because many companies face financial constraints, such a conclusion may be premature. A parallel literature, which attempts to control more fully for measurement error and allows non-convexities in marginal adjustment costs, has shown that neoclassical fundamentals are important determinants of investment. For example, Cummins and Hassett (1992) and Cummins, Hassett, and Hubbard (1994) used firm-level panel data to construct tax instruments for changes in tax-adjusted Tobin's $Q$ and the cost of capital, and found that both variables have sizable effects on investment following major U.S. tax reforms. Cummins, Hassett, and Hubbard (1995) found even larger responses following tax reforms in a sample of firms in 12 industrialized countries. Other studies showed that investment responds significantly to average $Q$ at relatively low values of $Q$ but little, if at all, at high values (see, e.g., Abel and Eberly 1996; Barnett and Sakellaris 1998). When this nonlinearity is ignored these studies found that the coefficient estimate on average $Q$ implies incorrectly that fundamentals have a negligible effect in the sample as a whole. Consistent with this firm-level research, Caballero,

\footnotetext{
${ }^{1}$ For a recent survey of the literature on capital-market imperfections and investment see Hubbard (1998).
} 
Engel, and Haltiwanger (1995) found that neoclassical fundamentals have large effects on investment in plant-level data. ${ }^{2}$

Given the results in this parallel literature, those who believe that financial factors drive investment face something of a puzzle. How can findings that support the neoclassical model be reconciled with the results of many studies that report a strong positive effect of internal funds on investment? We address this puzzle by building on the observation that neoclassical models perform well only if one has good measures of the fundamentals that drive investment. Although this requirement has long been recognized, it is often paid only lip-service in empirical research on investment. In particular, many studies have continued to use Tobin's $Q$ as a measure of fundamentals despite its disappointing track record.

We depart from prior work by employing firm-specific earnings forecasts from securities analysts to control for expected future profits. The forecasts are compiled by I/B/E/S International Inc., a private data vendor with extensive ties to the analyst community. Our approach side-steps the difficult problem of selecting a specific forecasting model for each firm. The professional analysts who track these companies do that for a living, and their expectations are observable. We use the analysts' earnings expectations in two ways. First, we include these expectations as instruments in a standard investment model that features Tobin's $Q$ as the proxy for fundamentals. In this way, we employ a larger and - we hope - more informative instrument set than in previous studies. Second, we construct a new measure of fundamentals from the earnings expectations, which we call "real $Q$ ". With real $Q$ serving as the control for the expected returns to investment, we estimate some models that circumvent the use of Tobin's $Q$ entirely.

To connect with previous empirical work on investment, we start with the specification often used to examine the role of financing constraints - that is, we regress investment on Tobin's $Q$ and cash flow, where investment and cash flow are both scaled by the replacement value of the capital stock. In this framework, the coefficient on cash flow measures its influence after controlling for expected future returns, and it should be zero if there are no binding financial constraints. We estimate this linear model

\footnotetext{
${ }^{2}$ For reviews of this more recent literature, see Caballero (1997) and Hassett and Hubbard (1997).
} 
with OLS and then with the generalized method of moments (GMM), as the OLS estimates are consistent only under restrictive conditions; our GMM procedure employs a standard instrument set, which contains lags of investment and cash flow (both scaled by the replacement value of the capital stock) and Tobin's $Q$. The results from these baseline linear regressions are consistent with those in much past work: We find small and sometimes insignificant coefficients on Tobin's $Q$, while cash flow has a significant effect on investment. However, the econometric properties of this model are poor: The residuals display a high degree of serial correlation, and diagnostic tests reject the hypothesis that the model and the instrument set are properly specified.

We then examine the robustness of this baseline model in several ways. Our alternative specifications include: (1) OLS estimation with real $Q$ replacing Tobin's $Q$ as the control for fundamentals and (2) GMM estimation with a variety of instrument sets that replace lags of Tobin's $Q$ with lags of either sales, analysts' earnings expectations, or both. The results obtained from all these alternatives are roughly the same - and in sharp contrast to those from the baseline specification. Notably, the controls for fundamentals now have large and statistically significant effects on investment. In this regard, the GMM estimates imply that the elasticity of the investment-capital ratio with respect to either Tobin's $Q$ or real $Q$ is generally above unity, when evaluated at the sample medians; the elasticity evaluated at the sample means is typically 25 to 50 percent greater. Moreover, we find that the coefficient on cash flow becomes uniformly insignificant, even for subsamples of firms that are often claimed to be liquidity constrained - those that pay no dividends and those without bond ratings. Finally, the econometric properties of the model improve dramatically. In our preferred GMM specifications, we no longer reject the model or the validity of the instruments, nor do we find evidence of serial correlation in the residuals (beyond that induced by our first-differencing of the data).

Our results strongly caution against using Tobin's $Q$ to estimate investment models. First, Tobin's $Q$ is a noisy control for fundamentals; only the portion that is correlated with the firm's past performance or its expected earnings helps to explain investment spending. Second, lags of Tobin's $Q$ appear to be invalid instruments; merely replacing them in the instrument set greatly improves the economic and statistical properties of 
the estimates. These problems likely indicate that Tobin's $Q$ is measured with error and that the error is serially correlated.

Another implication of our results is that analysts' earnings expectations convey valuable information about investment - certainly a lot more than Tobin's $Q$. Armed with just these expectations, we show that one can construct a model of firm-level investment with desirable properties and can forecast the time-series movements in aggregate investment with considerable accuracy. Nonetheless, the emphasis we place on analysts' expectations is more nuanced than in previous versions of this paper. As we document in section 4, most of the results we obtain with analysts' expectations as instruments also can be generated with an instrument set that includes only lags of sales, cash flow, and investment. This suggests that most of the information about investment in analysts' forecasts can be spanned with more easily available accounting data.

Our work is part of a growing effort to reassess previous research on investment and internal funds. In a well-known paper, Kaplan and Zingales (1997) used a simple model to show that the degree of a firm's financing constraint need not vary monotonically with its cash-flow sensitivity - thus calling into question the basic assumption behind many papers in this literature. To illustrate this point, they scrutinized the sample of low-dividend firms for which Fazzari et al. (1988) had found an especially strong correlation between investment and cash flow, holding fundamentals constant. Based on their reading of financial reports for these 49 firms, Kaplan and Zingales judged that the firms with the greatest cash flow sensitivity actually were unconstrained. ${ }^{3}$ Hayashi (1997) re-examined the results of another prominent paper in this literature, the Hoshi, Kashyap, and Scharfstein (1991) study of Japanese companies, which found that cash flow had a much stronger effect on investment for independent firms than for those with close ties to banks through their membership in a Keiretsu. Hayashi showed that this result is fragile. Using a parallel dataset that likely contains more accurate measures of investment and the capital stock, he found much less difference in cash flow coefficients across the two groups than did Hoshi et al. (1991) and no difference at all after removing four extreme data points.

\footnotetext{
${ }^{3}$ This assertion generated a lively debate; see the reply in Fazzari et al. (1996). Also see Cleary (1999), who used factor analysis to classify (a different set of) firms by degree of financial constraint and obtained results similar to those of Kaplan and Zingales.
} 
The studies that bear the closest resemblance to our paper are Erickson and Whited (1998) and Whited (1999). Both studies estimate investment equations using a GMM framework that explicitly allows for measurement error in Tobin's $Q$. Erickson and Whited (1998) provide a taxonomy of the possible sources of this error. ${ }^{4}$ Moreover, they estimate that the amount of measurement error in Tobin's $Q$ is substantial: Movements in true marginal $q$ account for as little as 40 percent of the observed variation in firm-level Tobin's $Q$. Although both studies obtain positive cash-flow coefficients in baseline OLS regressions, these coefficients become uniformly insignificant in their GMM procedure. We reach the same conclusion, but we use an estimation technique that hews much more closely to the methods typically employed in the investment literature. Our paper - combined with Kaplan and Zingales (1997), Hayashi (1997), Erickson and Whited (1998), and Whited (1999) - casts doubt on the evidence for liquidity constraints from the many studies that have estimated the $Q$ model augmented with measures of liquidity.

In the next section, we present the standard $Q$ model of investment, review how it is estimated, and discuss how analysts' earnings forecasts can be used to aid in estimation. Section 3 describes the data, while section 4 presents our results. The final section concludes and suggests directions for future research.

\section{Basic Investment Model}

\subsection{The Model}

The model we use is a standard one in the investment literature. The firm maximizes the expected present discounted value of future profits at time $t:^{5}$

$$
\mathrm{E}_{t}\left\{\sum_{s=t}^{\infty}\left(\prod_{j=t}^{s} \beta_{j}\right)\left[\Pi\left(K_{s-1}\right)-C\left(I_{s}, K_{s-1}, \omega_{s}\right)-I_{s}\right]\right\},
$$

\footnotetext{
${ }^{4}$ Two leading candidates include violations of the stringent assumptions needed for average $Q$ to equal the underlying marginal $q$ that drives investment, and inefficiencies in the equity market that would cause the firm's assessment of its prospects to differ from that embedded in Tobin's $Q$.

${ }^{5}$ The firm index $i$ is suppressed except when needed to avoid confusion.
} 
where $\mathrm{E}_{t}$ is the expectations operator conditional on the set of information available at the beginning of period $t, \Omega_{t-1} ; \beta_{s}=\left(1+\rho_{s}\right)^{-1}$ is the time $s$ discount factor; $I_{s}$ is gross investment; $K_{S-1}$ is the replacement value of the capital stock at the beginning of period $s ; \Pi\left(K_{s-1}\right)$ represents the revenue function; and $C\left(I_{s}, K_{s-1}, \omega_{s}\right)$ is the adjustment cost function, which includes the productivity shock $\omega_{s}$ as an argument. We assume that capital is the only quasi-fixed factor and that variable factors have been maximized out of $\Pi$. For convenience in presenting the model, we also assume that the price of investment relative to output is unity and that there are no taxes. In our empirical work we incorporate data on the after-tax price of investment to construct tax-adjusted Tobin's $Q$. The adjustment cost technology and the productivity shock are discussed in detail below.

Firms maximize equation (1) by choosing $I_{t}$ for all periods $t$, subject to the usual constraint on their capital stock:

$$
K_{t}=(1-\delta) K_{t-1}+I_{t},
$$

where $\delta$ is the rate of economic depreciation.

The first-order condition for this constrained maximization is:

$$
1+\frac{\partial C\left(I_{t}, K_{t-1}\right)}{\partial I_{t}}=q_{t}
$$

This equation shows that the full cost of acquiring and installing a unit of capital must equal $q$, the shadow price of capital. The shadow price evolves according to:

$$
\mathrm{E}_{t} \beta_{t+1}\left[\frac{\partial \Pi}{\partial K_{t}}-\frac{\partial C}{\partial K_{t}}\right]=q_{t}-(1-\delta) \mathrm{E}_{t}\left[\beta_{t+1} q_{t+1}\right] .
$$

Solving equation (3) for its stationary solution, we obtain the following expression for marginal $q$ :

$$
q_{t}=\mathrm{E}_{t} \sum_{s=t}^{\infty}\left[(1-\delta)^{s-t} \prod_{j=t}^{s} \beta_{j+1}\right]\left(\frac{\partial \Pi}{\partial K_{s}}-\frac{\partial C}{\partial K_{s}}\right) .
$$

Equation (4) states that marginal $q$ equals the present discounted value of the stream of net revenue generated by the marginal unit of undepreciated capital. 
Given an explicit form for the adjustment cost function, equation (2) can be manipulated to express the investment-capital ratio in terms of marginal $q$. The adjustment cost technology we choose is a standard one in the investment literature (adding the firm index $i$ ):

$$
C\left(I_{i t}, K_{i, t-1}\right)=\frac{\alpha}{2}\left(\frac{I_{i t}}{K_{i, t-1}}-\delta-\omega_{i t}\right)^{2} K_{i, t-1} .
$$

In this function, adjustment costs are convex in net investment. ${ }^{6}$ If we substitute $\frac{\partial C\left(I_{i t}, K_{i, t-1}\right)}{\partial I_{i t}}$ into equation (2) and rearrange terms, we obtain a simple equation linking investment to marginal $q$ :

$$
\frac{I_{i t}}{K_{i, t-1}}=\delta+\frac{1}{\alpha}\left(q_{i t}-1\right)+\omega_{i t}
$$

We assume that the productivity shock $\omega_{i t}$ is the sum of three mean-zero components:

$$
\omega_{i t}=v_{i}+v_{t}+\epsilon_{i t}
$$

where $v_{i}$ accounts for unobserved firm-specific heterogeneity, assumed to be constant over time; $v_{t}$ captures cyclical factors that have a common effect on all firms; and the final component, $\epsilon_{i t}$, is a stochastic disturbance to the firm's production process. We assume $\epsilon_{i t}$ is independently and identically distributed (iid) across firms, but can be serially correlated over time for each firm. ${ }^{7}$

Equation (6) is a standard empirical formulation of the neoclassical investment model under the null of perfect capital markets. ${ }^{8}$ Numerous studies have used this equation to test the null against the alternative in which financial factors affect investment. The usual procedure is to augment equation (6) with a variable - typically, cash

\footnotetext{
${ }^{6}$ Alternatively, adjustment costs could be modeled as a convex function of gross investment. The distinction is of little importance in the $Q$-model since the effect of depreciation is captured in the constant term of the regression equation.

${ }^{7}$ Alternatively, one can think of $\epsilon_{i t}$ as a measurement error or optimization error that allows the firm's first-order conditions to be satisfied only in expectation (from the perspective of the econometrician).

${ }^{8}$ There are several other ways to obtain empirical representations of the neoclassical investment model. The most common alternative is based on the Euler equation obtained by substituting equation (2) into (3) to eliminate terms in $q$.
} 
flow - that contains information about a firm's financial position. However, this approach yields valid tests only if marginal $q$ is accurately measured. The problem is that measures of internal net worth, like cash flow, signal not only the firm's financial position, but also may be correlated with its expected investment opportunities. If marginal $q$ is mismeasured, the estimated coefficient on cash flow could be positive and statistically significant even if the null model is correct. This concern is what motivates the empirical work in our paper.

\subsection{Estimation}

We use two alternative approaches to proxy for (unobservable) marginal $q$ in equation (6). First, to conform with much prior research, we use Tobin's average $Q$, defined as the ratio of the market value of the firm to the replacement value of its capital stock. Our particular measure contains a variety of tax adjustments and is defined by equation (A.1) in appendix A. Hayashi (1982) provided the theoretical basis for the use of Tobin's average $Q$, showing that it equals marginal $q$ when the firm has a linear homogeneous net revenue function and operates in perfectly competitive markets. In addition, the asset prices used to construct Tobin's $Q$ must provide a noise-free signal about the firm's fundamentals. Obviously, these are strong requirements. By itself, the substantial evidence of excess volatility in stock prices (see, e.g., Shiller 1989) raises questions about the use of Tobin's $Q$.

Our second proxy for fundamentals is based on analysts' earnings expectations. As we discuss in more detail below, the I/B/E/S data contain three variables that can be used to control for fundamentals: One- and two-year-ahead earnings forecasts, and a forecast of long-term earnings growth. We combine the forecasts into a tightly specified formulation called "real $Q$ ”. This specification, like that for Tobin's $Q$, relies on Hayashi's result that links measures of average $Q$ and marginal $q$ in equation (4). ${ }^{9}$

\footnotetext{
${ }^{9}$ Caballero and Leahy (1996) argue that average $Q$, not marginal $q$, is the correct measure of fundamentals when there are certain types of fixed costs. While it not possible for us to directly identify fixed costs in our firm-level data, our approach is consistent with their study since we use average $Q$ to approximate marginal $q$. Our empirical results support their suggestion to interpret the significance of cash flow in investment equations not as a signal of the presence of liquidity constraints, but as a variable that helps capture fundamentals.
} 
Real $Q$ is constructed in the following way. Let $E C F_{i t}$ and $E C F_{i, t+1}$ denote the firm's expected net income in periods $t$ and $t+1$, respectively, with each scaled by the replacement value of the capital stock at the beginning of period $t$, and let $E G R_{i t}$ denote the firm's expected growth rate of net income in the following periods. All these expectations are formed at the beginning of period $t$. We calculate the implied level of net income for periods after $t+1$ by growing out the average of $E C F_{i t}$ and $E C F_{i, t+1}$ at the rate of $E G R_{i t} .{ }^{10}$ The resulting sequence of net incomes (which we have scaled by the replacement value of the capital stock at the beginning of period $t$ ) defines real $Q_{i t}$ :

$$
\begin{aligned}
\text { Real } Q_{i t}= & \beta E C F_{i t}+\beta^{2}(1-\delta) E C F_{i, t+1} \\
& +\left(\frac{E C F_{i t}+E C F_{i, t+1}}{2}\right) \sum_{k=3}^{n}\left[\beta^{k}(1-\delta)^{k-1}\left(1+E G R_{i t}\right)^{k-2}\right] .
\end{aligned}
$$

This expression for real $Q$ mimics that for marginal $q$ in equation (4) except that we proxy for the unobserved future marginal products of capital with an approximation for the future average products based on the I/B/E/S earnings forecasts.

We set the constant discount factor, $\beta$, to 0.91 (reflecting a 10 percent nominal interest rate, $\rho=0.10$ ), and the depreciation rate to the sample mean of the data, about 0.15. Our empirical results were similar when we used firm- or industry-specific data on discount factors (based on S\&P bond ratings) and depreciation rates. In principle, the value of $n-$ the horizon for calculating real $Q-$ should be infinity. However, the analysts estimate $E G R$ over a horizon of no more than five years, so we lack information for the later years. We experimented with values of $n$ ranging from five to ten years and found that our qualitative results were not sensitive to this choice. Thus, somewhat arbitrarily, we set $n$ equal to ten years in equation (8). ${ }^{11}$

We constructed two other variants of real $Q$ for our empirical analysis. The first is what we call "terminal value real $Q$ ", which augments real $Q$ with an estimate of

\footnotetext{
${ }^{10}$ We grow out the average of the one- and two-year-ahead forecasts rather than the two-year-ahead forecast because I/B/E/S defines $E G R$ as the expected trend growth of the company's earnings, not the growth rate from the two-year-ahead forecast of earnings.

${ }^{11}$ The expression for real $Q$ is also less than ideal for one additional reason. To approximate the average product of capital, the projected net income for a given future period should be scaled by the beginningof-period capital stock for that period. However, future values of the firm's capital stock are unknown forcing us to use the beginning-of-period $t$ value instead.
} 
earnings beyond year ten:

Terminal Value Real $Q_{i t}=$ Real $Q_{i t}$

$$
+\frac{1}{\rho}\left[\beta^{n+1}(1-\delta)^{n}\left(1+E G R_{i t}\right)^{n-1}\left(\frac{E C F_{i t}+E C F_{i, t+1}}{2}\right)\right] .
$$

The terminal value correction is, in effect, a perpetuity based on the firm's net income in period $n+1$ (i.e., year 11). This formulation implies that the firm's growth opportunities cease after that point. Depending on the firm and industry, eleven years may be an overor underestimate. Unfortunately, we do not have any firm-level data to construct more precise measures. Moreover, even if we had richer data there is no clearly preferred method for calculating a firm's terminal value, as noted by Brealey and Myers (1996) (p. 78). We follow their suggestion to use this particular method because it "forces managers to remember that sooner or later the competition catches up."

The second variant of real $Q_{i t}$, which we call "long-run real $Q$ ", uses only two-yearahead earnings and long-term growth forecasts:

$$
\text { Long Run Real } Q_{i t}=\text { Real } Q_{i t}-\beta E C F_{i t} \text {. }
$$

By excluding the one-year-ahead forecasts we can examine whether investment responds more to near-term or longer-run expectations of profitability. Also, this measure addresses the concern that real $Q$ could capture liquidity effects because its first term $\left(\beta E C F_{i t}\right)$ is highly correlated with realized period- $t$ cash flow, our proxy for changes in internal net worth. Using long-run real $Q$ gives cash flow the best possible chance to affect investment in our regressions.

Our approach to constructing measures of fundamentals is an alternative to the VAR-based methods used by Abel and Blanchard (1986) and Gilchrist and Himmelberg (1995, 1999). Abel and Blanchard (1986) derive a linear approximation to $Q$, and then use a VAR estimated with aggregate data for US manufacturing to project the future discount rates and marginal returns to capital that appear in the approximation. Gilchrist and Himmelberg apply a variant of this technique to firm-level panel data. Our approach sidesteps the need for a VAR by relying on the analysts to project future earnings. However, the VAR-based methods and our approach both invoke restrictive assumptions - 
most notably, the assumption of quadratic adjustment costs, which delivers the linear relationship between investment and $Q$. To examine whether this assumption affects our results, a previous version of this paper estimated a semiparametric version of the model that allows $q$ to affect investment nonlinearly. We omitted these results because the discussion of the semiparametric estimator is relatively involved and our empirical results were essentially the same as those presented here, giving us confidence that the strong assumptions we invoke to construct real $Q$ and its variants are not driving our results.

A number of variables could be used to proxy for changes in internal net worth. We follow the bulk of the literature by using the ratio of current cash flow, defined as the sum of net income and depreciation, to beginning-of-period capital, $C F_{i t} / K_{i, t-1} \cdot{ }^{12}$ Thus, the equation we estimate is:

$$
\frac{I_{i t}}{K_{i, t-1}}=\delta+\frac{1}{\alpha} Q_{i t}+\gamma \frac{C F_{i t}}{K_{i, t-1}}+\omega_{i t}
$$

where $Q_{i t}$ represents either Tobin's $Q$, real $Q$, or one of the variants of real $Q$. The test for liquidity constraints with this equation is straightforward. If the estimate of $\gamma$ is positive and statistically significant, we would conclude that some form of liquidity constraint is currently binding, as firms evidently invest out of cash flow, even after controlling for fundamentals. In contrast, if $\gamma$ is statistically insignificant from zero, we would conclude in favor of the null neoclassical model.

Questions can be raised, however, about the power of this test to detect liquidity constraints when they actually exist. In that case, the expectations embedded in Tobin's $Q$ (or real $Q$ and its variants) could well include the anticipated effects of liquidity constraints, so that these variables would not be pure measures of fundamentals. Accordingly, $Q$ might fully explain investment spending, leaving no role for cash flow. There is, no doubt, an element of truth in this concern. However, Chirinko (1997) showed that, in the presence of financing constraints, $Q$ generally is not a sufficient statistic for investment. Financial variables, such as cash flow or the interest coverage

\footnotetext{
${ }^{12}$ Actually, the literature's focus on current-period cash flow puzzles us, since marginal $q$ includes the cash flow generated during the first period in which the investment good is in service (see equation (4)). Indeed, this term should receive the largest weight in the calculation of $q$. Nonetheless, we used currentperiod cash flow to maintain comparability with prior work. In an earlier version of this paper we also used previous-period measures of liquidity. Our conclusions are unaffected when using this timing.
} 
ratio, will also affect investment whenever the firm's cost premium for external funding depends on its current earnings. This dependence seems quite plausible, as investors will be less concerned about the prospect of financial distress - and the associated costs - for firms generating substantial current profits. Thus, cash flow should be expected to influence investment in equation (11) for constrained firms. Those who believe otherwise should recognize that they are impugning not only our approach but all the investment-cash flow regressions reported in previous research.

We estimate equation (11) using OLS and GMM. The OLS results will be biased and inconsistent to the extent that the current-period regressors are correlated with the error term. We present these results despite their econometric problems so that our findings can be compared to the numerous prior studies that have employed OLS. Our primary estimator is GMM, which yields consistent estimates provided that the instruments are uncorrelated with the error term. We use a variety of instrument sets - including some that contain analysts' earnings forecasts - to examine whether the results are sensitive to the choice of instruments.

Prior to estimation, we first-difference equation (11) to remove the firm-specific error component, $v_{i}$, and introduce time dummies as regressors for $v_{t}$ in each period. When $\epsilon_{i t}$ is serially uncorrelated, its first-difference is MA(1), in which case lagged endogenous variables dated at $t-2$ and earlier are valid instruments for the differenced equation. If the model is misspecified the error term may display higher-order serial correlation, in which case even instruments dated at $t-2$ and before may be invalid.

We test the validity of each instrument set in two ways. First, we report the $p$-value of the $m_{2}$ test proposed by Arellano and Bond (1991) to detect higher-order serial correlation in the residuals. ${ }^{13}$ Second, we report the $p$-value of the Sargan statistic (also know as Hansen's $J$-statistic), which tests the joint null hypothesis that the model is correctly specified and that the instruments are valid (for further details see, e.g., Arellano and Bond 1991; Blundell, Bond, Devereux, and Schiantarelli 1992). ${ }^{14}$ Unfortunately, it is

\footnotetext{
${ }^{13}$ The $m_{2}$ statistic, which has a standard normal distribution under the null, tests for nonzero elements on the second off-diagonal of the estimated serial covariance matrix. We also tested, but (to conserve space) do not report, whether the first off-diagonal has nonzero elements. Since first-differencing should introduce an MA(1) error we were not surprised to find that we rejected the null of no first-order serial correlation in virtually every case.

${ }^{14}$ Formally, the Sargan statistic is a test that the overidentifying restrictions are asymptotically distributed $\chi_{(n-p)}^{2}$, where $n$ is the number of instruments and $p$ is the number of parameters.
} 
not possible to test either hypothesis separately. Thus, considerable caution should be exercised in interpreting why the null is rejected - the instruments may be invalid due to serial correlation in the residuals, the model may be misspecified, or both problems may be present.

In summary, our empirical framework extends the usual method for estimating investment-cash flow regressions by using Tobin's $Q$ and real $Q$ as alternative controls for fundamentals and by using a variety of instrument sets in the GMM estimation. We employ this framework to assess the information content of analysts' earnings forecasts and to evaluate the robustness of evidence for capital market imperfections from prior studies.

\section{Data}

We estimate the model using firm-level data from two sources. The data on investment, the capital stock, Tobin's $Q$, and cash flow, and the variables used to split the sample are from Compustat, while the data on expected earnings are from I/B/E/S International Inc. We briefly discuss the Compustat data and then describe in greater detail the $\mathrm{I} / \mathrm{B} / \mathrm{E} / \mathrm{S}$ data.

\subsection{Compustat Dataset}

The Compustat dataset is an unbalanced panel of firms from the industrial, full coverage, and research files. The variables we use are defined as follows. The replacement value of the capital stock is calculated using the standard perpetual inventory method with the initial observation set equal to the book value of the firm's first reported net stock of property, plant, and equipment (data item 8) and a firm-level rate of economic depreciation constructed using the method in Cummins et al. (1994). Gross investment is defined as the direct measure of capital expenditures in Compustat (data item 30). Cash flow is the sum of net income (data item 18) and depreciation (data item 14). Both gross investment and cash flow are divided by the beginning-of-period replacement value of the capital stock. The construction of tax-adjusted Tobin's $Q$ is discussed in detail in appendix A. The implicit price deflator (IPD) for total investment for the firm's 
three-digit SIC code is used to deflate the investment variable and in the perpetual inventory calculation of the replacement value of the firm's capital stock. The three-digit IPD for gross output is used to deflate cash flow. These price deflators are obtained from the NBER/Census database (http://www.nber.org/nberprod). We use Compustat data on the firms' S\&P bond rating and dividend payouts to split the sample, isolating those firms that may a priori face financial constraints.

\section{$3.2 \quad \mathrm{I} / \mathrm{B} / \mathrm{E} / \mathrm{S}$ Dataset}

We employ data on expected earnings from I/B/E/S International Inc., a private company that has been collecting earnings forecasts from securities analysts since 1971. To be included in the I/B/E/S database, a company must be actively followed by at least one securities analyst, who agrees to provide I/B/E/S with timely earnings estimates. According to I/B/E/S, an analyst actively follows a company if he or she produces research reports on the company, speaks to company management, and issues regular earnings forecasts. These criteria ensure that $\mathrm{I} / \mathrm{B} / \mathrm{E} / \mathrm{S}$ data come from well-informed sources. The I/B/E/S earnings forecasts refer to net income from continuing operations as defined by the consensus of securities analysts following the firm. Typically, this consensus measure removes from earnings a wider range of non-recurring charges than the "extraordinary items" reported on firms' financial statements.

For each company in the database, I/B/E/S asks analysts to provide forecasts of earnings per share over the next four quarters and each of the next five years. We focus on the annual forecasts to match the frequency of our Compustat data. In practice, few analysts provide annual forecasts beyond two years ahead. I/B/E/S also obtains a separate forecast of the average annual growth of the firm's net income over the next three to five years - the so-called "long-term growth forecast" which we denoted above as $E G R_{i t}$. When calculating their forecasts of long-term growth, I/B/E/S instructs analysts to ignore the current state of the business cycle and to project, instead, the expected trend growth of the company's earnings. Thus, the long-term growth forecast should contain information not in the one-year-ahead and two-year-ahead forecasts, which necessarily will be affected by current conditions. And for companies that make investment decisions based on the expected long-term returns to capital - in accord 
with the neoclassical model - the long-term growth forecast should be an important determinant of investment.

We abstract from any heterogeneity in analyst expectations for a given firm-year by using the mean across analysts for each earnings measure (which I/B/E/S terms the “consensus" estimate). We multiply the one-year-ahead and two-year-ahead forecasts of earnings per share by the number of shares outstanding to yield forecasts of future earnings levels. As noted above, we generate the variables $E C F_{i t}$ and $E C F_{i, t+1}$ by scaling these forecasts of net income in periods $t$ and $t+1$ by the replacement value of the capital stock at the beginning of period $t$.

The one-year-ahead and two-year-ahead forecasts are available from 1976 but the long-term growth forecasts were not collected until 1981, which constrains the starting point of our sample. The data coverage increases gradually over time, with the Compustat universe largely covered by 1994. At the end date of our sample, December 1995, the I/B/E/S database included about 5,000 US corporations that were actively followed by securities analysts, plus nearly as many defunct companies that were previously covered.

An important issue concerns the dating of the I/B/E/S earnings forecasts. Shortly after the end of a firm's fiscal year, securities analysts send I/B/E/S an initial forecast of earnings for the fiscal year that has just begun and for the next fiscal year. These are what we have called the one-year-ahead and two-year-ahead forecasts. As the fiscal year progresses, analysts process new information and file revised forecasts with I/B/E/S, yielding a sequence of one-year-ahead and two-year-ahead consensus forecasts for the firm. Similarly, I/B/E/S posts a sequence of consensus long-term growth forecasts over the fiscal year. We use the first forecast in each sequence. ${ }^{15}$ By relating investment in year $t$ to earnings forecasts issued at the beginning of the year, we reduce the risk of using more information than the firm actually has when it determines investment spending for the year. ${ }^{16}$

\footnotetext{
${ }^{15}$ The first forecast is within 2 months of the beginning of the fiscal year for 75 percent of our sample and within 3 months for 97 percent of our sample.

${ }^{16}$ With time-to-build lags, however, investment in year $t$ may have been determined in large part or completely by information available before the start of year $t$. In this case, the GMM results we present are consistent as long as the time-to-build lags do not exceed two years since we use an instrument set containing earnings forecasts formed at the beginning of year $t-2$ and earlier.
} 
Our working assumption is that $\mathrm{I} / \mathrm{B} / \mathrm{E} / \mathrm{S}$ earnings forecasts provide valuable information about the expected returns to investment. The empirical results in the next section support this view, as does a large literature on the properties of earnings expectations. ${ }^{17}$ Nonetheless, analysts' forecasts may not contain all available information. While some studies have failed to reject rationality (see, e.g., Keane and Runkle 1998), others have found that analysts' forecast errors are predictable (see, e.g., Brown 1996a). For our purposes, full rationality is not crucial; the I/B/E/S forecasts will have value as long as they provide a better proxy for fundamentals than do Tobin's $Q$ and its lags, which we show to be the case.

\subsection{Data Samples Used for Estimation}

We construct two samples from the firm-level data. The first, which represents our primary sample, includes all firms with at least four consecutive years of complete Compustat and I/B/E/S data. We require four years of data to allow for first-differencing and the use of lagged variables as instruments. We determine whether the firm satisfies the four-year requirement after deleting observations that fail to meet a standard set of criteria for data quality (described below). The second, and larger, sample is constructed without regard for the availability of the I/B/E/S earnings expectations. It contains all annual observations for firms with at least four consecutive years of complete Compustat data - again, after imposing standard deletion rules. This larger sample is intended to approximate the datasets used in previous research, which were not limited to firms with analyst coverage. ${ }^{18}$

We deleted observations for the following reasons (the percent of the primary sample that the rule deletes is in parentheses): (1) the ratio of investment to beginning-ofperiod capital is greater than unity or less than zero (14 percent); (2) tax-adjusted $Q$ is less than -1, its theoretical minimum, or greater than 30 (5.5 percent); (3) real $Q$ is less than zero or greater than 30 (2 percent); and, finally, (4) we also deleted the first and

\footnotetext{
${ }^{17}$ For surveys of the literature see Coggin (1990); and Brown (1993, 1996a); Givoly and Lakonishok (1984). For an annotated bibliography covering more than 400 articles on earnings expectations see Brown (1996b).

${ }^{18}$ The requirement that each firm be in the panel for at least four years eliminates about 21 percent of the potential observations for the primary sample and about 19 percent of those for the Compustat-only sample.
} 
last half-percentiles in $C F / K .^{19}$ These types of rules are common in the literature and we employ them to maintain comparability to previous studies; in section 4.4 we discuss how our results are affected when we use different cut-offs. The first and fourth cut-offs are intended to eliminate observations that reflect especially large mergers, extraordinary firm shocks, or Compustat coding errors. The second and third rules are intended to remove firms for which fundamentals may be seriously mismeasured.

\section{Empirical Results}

\subsection{Sample Statistics}

Table 1 provides the mean, median and standard deviation for the key variables in the two samples that we use. Column 1, labeled "Compustat", presents summary statistics for the larger sample that consists of firms with the necessary Compustat data, irrespective of whether I/B/E/S data are available. Column 2, labeled "I/B/E/S", refers to the primary sample for our empirical work, which includes firms for which we have the required data from both Compustat and I/B/E/S. The remaining columns refer to splits of the two samples.

As shown in column 2, the median firm in our primary sample is mid-sized, with real (1992 dollar) sales of $\$ 764$ million, and has been expanding fairly rapidly. This is evident from both the median growth rate of real sales (4.4 percent annually) and the high median ratio of annual investment outlays to beginning-of-period capital stock (0.26). In addition, the financial markets evidently believe that the median firm - with a tax-adjusted Tobin's $Q$ that exceeds 2.6 - has valuable investment opportunities. ${ }^{20}$ However, as indicated by the large standard deviation for each variable, our sample includes a broad range of firms with regard to size, investment behavior, and financial health.

\footnotetext{
${ }^{19}$ For comparison the first exclusion rule deletes about 16 percent of the Compustat-only sample, the second about 6.5 percent, and the fourth also one percent.

${ }^{20}$ The median value of real $Q$, at 0.98 , is less than half that of tax-adjusted Tobin's $Q$. Recall that we constructed real $Q$ from analyst expectations of earnings net of interest payments. Thus, the returns to debt holders are omitted from the numerator of real $Q$, causing it to be smaller than Tobin's $Q$, which captures all of the firm's liabilities.
} 
Our primary sample omits about 25 percent of the nearly 12,000 observations in the Compustat sample (column 1), owing to the absence of $\mathrm{I} / \mathrm{B} / \mathrm{E} / \mathrm{S}$ data. We were concerned that these omissions might make this sample unrepresentative of the Compustat universe - and, in particular, skew it away from the firms often thought to be liquidity constrained. However, as can be seen by comparing columns 1 and 2, the Compustat and I/B/E/S samples have similar characteristics. Indeed, the means, medians and standard deviations of all variables except sales are nearly the same across the two samples. The firms in the I/B/E/S sample are somewhat larger than those in the Compustat sample (median real sales of $\$ 764$ million versus $\$ 510$ million). Nonetheless, about 40 percent of the observations in the I/B/E/S sample are drawn from firms with real sales below the median value of the Compustat sample, indicating that the I/B/E/S/ sample does not seriously underweight smaller firms.

One might still be concerned that the two samples may not match up after they are partitioned in standard ways. The remaining columns in the table show that this concern appears unwarranted as well. Focus, for example, on columns 9 and 10, which summarize the data for firms that lacked a bond rating in the prior year. The differences across the Compustat and I/B/E/S samples are slight, except for the somewhat larger size of the median firm in the I/B/E/S sample (\$361 million in real sales, versus $\$ 252$ million for Compustat firms). However, the I/B/E/S sample largely preserves the size difference between rated and unrated firms that is evident in the Compustat sample. If unrated firms (within the Compustat universe) really do face greater liquidity constraints than firms with rated bonds, we should be able to detect this pattern with our I/B/E/S sample.

As another check we constructed the aggregate ratios of investment to beginning-ofperiod capital for the $\mathrm{I} / \mathrm{B} / \mathrm{E} / \mathrm{S}$ and Compustat samples. We then regressed the aggregate Compustat ratio on the aggregate $\mathrm{I} / \mathrm{B} / \mathrm{E} / \mathrm{S}$ ratio; the $R^{2}$ from this regression is the total variation in the Compustat ratio explained by the I/B/E/S ratio. This regression yields an estimated slope coefficient of 0.876 with a standard error of 0.078 and an $R^{2}=0.927$. In first differences the same regression yields a coefficient estimate of 1.000 with a standard error of 0.120 and an $R^{2}=0.886$. In both regressions the intercepts are statistically insignificant from zero. The nearly one-for-one movement in these ratios 
indicates that the I/B/E/S sample and the broader Compustat sample display about the same investment behavior over time.

\subsection{OLS Estimation Results}

To begin our empirical analysis, Table 2 presents OLS estimates of the first difference of equation (11) using two different variables to control for fundamentals: tax-adjusted Tobin's $Q_{i t}$ and real $Q_{i t}$, constructed using the I/B/E/S earnings forecasts. The top panel reports estimates obtained from the Compustat sample, while the middle and bottom panels report estimates from the I/B/E/S sample. The dependent variable for all regressions is the first difference of the ratio of investment to beginning-of-period capital, and the explanatory variables always include a full set of year dummies and a constant term. ${ }^{21}$

Focusing on the top panel, column 1 reports the estimates from a regression with Tobin's $Q$ and the ratio of cash flow to beginning-of-period capital as explanatory variables. This regression has been estimated in many previous studies. As is typically found, the coefficient on Tobin's $Q$ is positive and statistically significant, but very close to zero (0.016 in our case); this estimate implies marginal adjustment costs that are implausibly high - more than $\$ 5$ for a $\$ 1$ investment. The coefficient on $C F_{i t} / K_{i, t-1}$ is strongly significant, though its value $(0.15)$ is at the lower end of the range of previous estimates. Scanning across columns 2 through 5, the same pattern holds for our two sets of sample splits: Small but significant coefficients on Tobin's $Q$ (ranging from 0.012 to 0.029 ) and significant coefficients on cash flow (ranging from 0.11 to 0.19 ).

Consistent with other studies, we estimate the cash-flow coefficient to be significantly larger for unrated firms than for those with a bond rating. However, firms that paid no dividend in the prior year have a smaller cash-flow coefficient than do dividend-paying firms, contrary to the presumption that low-dividend firms are financially constrained. This result does not concern us, in part because there is already conflicting evidence in the literature regarding dividend splits. For example, while

\footnotetext{
${ }^{21}$ The careful reader will notice that the number of firms in each of the two-way sample splits is less than the total number of firms in the first column. The requirement that the firm have four consecutive years of data means that we lose some firm-year observations when firms change status (e.g., begin paying dividends toward the end of the sample period).
} 
Fazzari et al. (1988) estimated that investment by low-dividend firms was relatively sensitive to cash flow, Gilchrist and Himmelberg (1995) found the reverse. Moreover, the theoretical results in Kaplan and Zingales (1997) and Chirinko (1997) cast doubt on the whole premise underlying such comparisons by showing that the size of cash-flow coefficients need not have a monotonic relation with the severity of financial constraints. The intuition is that the sensitivity of investment to cash flow also depends on the specifics of the firm's production technology. Our results from the dividend split may simply illustrate this point.

The middle panel presents the results obtained by estimating the same regression on the I/B/E/S sample. The standard errors on the coefficient estimates generally increase in size - as would be expected with the switch to a smaller sample - but the estimates themselves are quite similar to those in the top panel. This similarity is reassuring because we have no choice but to use the I/B/E/S sample once we introduce the analysts' earnings expectations either through real $Q$ or as instruments.

The bottom panel shows the effect of substituting real $Q$ for Tobin's $Q$, while keeping everything else unchanged from the middle panel. The overall fit of the regression improves, as indicated by the higher $R^{2}$ in every column except one. In addition, the coefficient on real $Q$ is highly significant, demonstrating that the earnings expectations embedded in real $Q$ do convey useful information about investment spending. ${ }^{22}$ Even more striking, the cash-flow coefficient is much smaller than in the middle panel ranging now from just 0.015 to 0.057 - and is statistically significant in just two of the five columns.

These results raise questions about the liquidity effects found in studies that have used Tobin's $Q$ to control for fundamentals. When we substitute a simple linear function of analysts' earnings expectations, which arguably contain less noisy information concerning firms' true neoclassical fundamentals, we find much less evidence of liquidity effects. However, the OLS results presented in table 2 and in previous studies will be biased if, as seems likely, the explanatory variables are correlated with the error term. Thus, our OLS results are nothing more than a first pass at the data that allows

\footnotetext{
${ }^{22}$ The larger coefficient on real $Q$ arises, in part, because real $Q$ is typically only one-half to one-third the size of Tobin's $Q$ and varies within a narrower range (see Table 1 ).
} 
us to connect with prior work. We now turn to GMM estimation to circumvent the potential bias in the OLS estimates and to test whether the strong assumptions needed to construct real $Q$ influence the results. If internal funds are unimportant in table 2 because analysts' forecasts truly measure fundamentals better than has been done in the past - and not simply because of the restrictive assumptions behind real $Q$ - then we should obtain similar results when we use the analysts' forecasts as instruments for Tobin's $Q$ and real $Q$.

\subsection{GMM Estimation Results}

Table 3 provides the GMM estimates of the first-differenced investment equation using the I/B/E/S sample and either tax-adjusted Tobin's $Q$ or real $Q$ as the control for fundamentals. We implement GMM with two alternative sets of instrumental variables. The upper panel displays the results for an instrument set that includes the period $t-2$, $t-3$, and $t-4$ values of $I / K$, tax-adjusted Tobin's $Q$, and $C F / K$, as well as a full set of year dummies and a constant (which are included in all instrument sets). With this instrument set, the coefficients on Tobin's $Q$ (shown in the odd-numbered columns) are small and statistically insignificant, while the coefficients on cash flow are large (ranging from 0.229 to 0.378 ) and highly significant in all samples except the no-dividend group, where the estimate is significant at the 10 percent level.

Despite the sizable cash-flow coefficients, these results should not be taken as evidence for the presence of liquidity constraints. Most notably, every set of estimates fails the Sargan test. This means that the model is misspecified, the instruments are invalid, or both. As another sign of econometric problems, the $m_{2}$ test provides evidence of serial correlation in the residuals in two of the five cases. ${ }^{23}$

The even-numbered columns show the effect of replacing Tobin's $Q$ with real $Q$ as the control for fundamentals. As shown, the coefficient on real $Q$ is significant in all cases except one, in contrast to the uniform insignificance of Tobin's $Q$. In addition, the coefficient on cash flow turns negative in three cases, and is never statistically

\footnotetext{
${ }^{23}$ We would also note that the sample splits fail to produce significantly larger cash-flow coefficients for the no-dividend and unrated firms than for other groups. Many would regard this result, by itself, as evidence against liquidity constraints. However, we would take a more agnostic stand, given the theoretical work, discussed above, that cautions against trying to infer whether liquidity constraints exist by comparing cash-flow sensitivities across sample splits.
} 
significant. These estimates certainly do not support a liquidity effect on investment. But we would not rely on these results, as they also fail the Sargan test virtually across the board (although the residuals show less evidence of serial correlation).

One possible explanation for the pattern of results in the top panel is that the instruments are weaker for Tobin's $Q$ than for real $Q$, which could allow cash flow to have a greater effect on investment in the Tobin's $Q$ regression. However, the instruments for Tobin's $Q$ are actually quite powerful. For example, in the full I/B/E/S sample, the $F$-test for the joint insignificance of the full set of instruments in the "first-stage" regression has a $p$-value below 0.0001 . Applying the same test to the "first-stage" regression for real $Q$ also yields an infinitesimal $p$-value. Thus, weak instruments do not appear to be driving our results.

Another possible explanation focuses on serially correlated measurement error in Tobin's $Q$ - resulting, perhaps, from persistent deviations of asset prices from their fundamental value. This would make lags of Tobin's $Q$ inadmissible as instruments. To test this hypothesis, we drop lags of Tobin's $Q$ from the instrument set, and replace them with lags of another variable that should help measure the firm's "fundamentals", the ratio of sales to beginning-of-period capital, $Y / K$. In all other respects, this instrument set is the same as the prior one.

As shown in the lower panel, this seemingly minor change to the instrument set has a considerable effect on the estimates. The coefficients on Tobin's $Q$ and real $Q$ are dramatically larger than those in the upper panel, and they are almost always significant. The estimates of the cash-flow coefficient vary widely across the columns of the table, but the only statistically significant one is negative; this contrasts with the positive, significant coefficients shown in the upper panel when we used Tobin's $Q$ as the control for fundamentals. In addition, the Sargan test is now not rejected (at the five percent level) in eight of ten cases. The $m_{2}$ test for serial correlation is also not rejected in eight of ten cases. Accordingly, we have more faith in these estimates than those presented in the upper panel or in table $2 .^{24}$

As a check on our results, we repeated the GMM estimation on the larger Compustat sample. Table 4 reports these results, omitting the specifications that involve real

\footnotetext{
${ }^{24}$ One might be concerned that the "fundamental" instruments are weak. However, this is not the case. In the full I/B/E/S sample, the $F$-test of this instrument set for both Tobin's $Q$ and real $Q$ has a $p$-value below 0.0001 .
} 
$Q$, which we cannot calculate for every firm in this sample. Although the coefficient estimates vary somewhat across the two tables, the basic conclusions are the same. In particular, with lags of Tobin's $Q$ in the instrument set (the upper panel), we again generate positive and (mostly) significant cash-flow coefficients but fail the Sargan and $m_{2}$ tests in all cases. When we remove lags of Tobin's $Q$ from the instrument set and replace them with lags of the sales-capital ratio (the lower panel), the coefficient on Tobin's $Q$ jumps to values that are economically and statistically significant. The coefficient estimates on cash flow - while sometimes large - become uniformly insignificant, and the Sargan and $m_{2}$ tests now fail in roughly half the cases rather than across the board. Hence, as in table 3, the estimates with the more desirable econometric properties provide no evidence of credit constraints.

Looking at tables 3 and 4 together, it's startling that the statistical and economic properties of the estimates improve so dramatically when we do nothing more than remove the lags of Tobin's $Q$ from the instrument set. To our knowledge, no other investment study has undertaken this simple experiment, the results of which raise questions about the evidence for liquidity constraints from a number of other investment papers. We discuss the existing literature in more detail after we present the rest of our econometric results.

The results presented so far highlight the importance of choosing instruments that contain considerable information about the firm's fundamentals and that have desirable statistical properties. By these criteria, analysts' earnings expectations are obvious candidates as instruments. Accordingly, we created a larger instrument set that includes the period $t-2, t-3$, and $t-4$ values of $I / K, C F / K, Y / K$, the ratios of the analysts' forecasts of one-year-ahead and two-year-ahead earnings to beginning-of-period capital, and the long-term growth forecast.

The top panel of table 5 reports the GMM estimation results with this larger instrument set. In all other respects, the estimation method and data are identical to those used to generate the results in the bottom panel of table 3 . As can be seen, the coefficients on Tobin's $Q$ and real $Q$ are somewhat smaller than those shown at the bottom of table 3, though they remain significant in most cases. The coefficients on $C F / K$ are all insignificant, as they were with the smaller instrument set. However, the performance 
with respect to the Sargan test has deteriorated, with the model now being rejected in seven of the ten columns.

The middle panel examines how the results change when we omit $C F / K$ and $Y / K$ from the instrument set, while leaving in the lags of analyst expectations and $I / K$. As shown, the point estimates are quite similar to those in the lower panel of table 3: the coefficients on Tobin's $Q$ and real $Q$ are large and statistically significant, while those on $C F / K$ are insignificant. Using this instrument set, however, yields more precise coefficient estimates on Tobin's $Q$ and real $Q$, as we would expect if lagged earnings expectations are more informative measures of the determinants of investment than lagged accounting variables. Moreover, we find almost no evidence of model misspecification from the Sargan test or the $m_{2}$ test for serial correlation. In fact, comparing these results with those at the bottom of table 3 , the statistical properties of the model improve when the analyst expectations replace the "fundamental" variables in the instrument set.

If firms make investment decisions based on the expected long-term returns to capital - in accord with the neoclassical model - the two-year-ahead and long-term growth forecasts should contain the most information about the fundamentals. To test this idea, the bottom panel reports the results obtained when we omit the one-year-ahead expectations from the instrument set in the middle panel. The coefficients on Tobin's $Q$ and real $Q$ are similar to those in the middle panel, and they are uniformly significant, despite some increase in their standard errors. The coefficient on $C F / K$ remains insignificant in all cases. These estimates confirm that, indeed, it is the longer-range projections that drive our results. Moreover, the one-year-ahead forecasts may not be valid instruments, owing to correlation with the contemporaneous error term. As shown in the bottom panel, when these forecasts are removed from the instrument set, we no longer reject the Sargan test at the five percent level for any specification.

We can use the estimates on Tobin's $Q$ and real $Q$ in the middle and bottom panels of table 5 to calculate the range of implied elasticities of the investment-capital ratio with respect to the fundamental variable. For both Tobin's $Q$ and real $Q$ the elasticity is always above unity when evaluated at median values of the variables; the elasticity is 25 to 50 percent larger when evaluated at means. These estimates indicate that investment spending is highly sensitive to fundamentals. The estimates also imply that marginal 
adjustment costs for a $\$ 1$ investment are all less than $\$ 1$, evaluated at either the means or medians of the sample variables.

Table 6 addresses two potentially important concerns about the results obtained with real $Q$ as the control for fundamentals. First, the analysts' one-year-ahead forecasts built into real $Q$ are highly correlated with our liquidity variable, which could reduce the power of tests to identify liquidity effects if they actually exist. To address this concern, table 6 reports GMM estimates obtained with long-run real $Q$ from equation (10) as the control for fundamentals; recall that long-run real $Q$ removes the one-period-ahead forecasts, $E C F_{i t}$, from our construction of real $Q$. The second concern about the I/B/E/S forecasts is that they have a finite horizon, and thus fail to impound the full return to long-lived investment. To address this concern, we report the results obtained with another variant of real $Q$ - the terminal-value real $Q$ shown in equation (9), which adds an estimate of the residual value from the period beyond our forecast horizon.

The odd-numbered columns report the results when we use long-run real $Q$ in place of real $Q$. In all other respects, the specification is identical to that in the middle panel of table 5. As can be seen, the coefficients on long-run real $Q$ are all statistically significant, while the cash-flow coefficients remain uniformly insignificant. The Sargan test is not rejected in four of the five columns, and there is no evidence of second-order serial correlation. The results are strikingly similar to those in the middle panel of table 5 , showing that the presence of one-period-ahead forecasts in real $Q$ does not bias us against finding liquidity effects. ${ }^{25}$ The coefficient estimates on terminal-value real $Q$, in the even-numbered columns, are smaller than those on real $Q$ in the middle panel of table 5 , likely because the mean of terminal-value real $Q$ is substantially greater than

${ }^{25}$ These results rule out the following interpretation of investment behavior suggested to us by Owen Lamont. Suppose the firm plans its investment spending with a one-year lead and follows a rule of thumb under which its period $t$ investment reflects its expected cash flow in that period:

$$
\frac{I_{i t}}{K_{i, t-1}}=\delta+\gamma \mathrm{E}_{t} \frac{C F_{i t}}{K_{i, t-1}}+\omega_{i t}
$$

where $E_{t}$ is the expectation operator that uses beginning-of-period information. If this were the true model but we instead estimated equation (11) using real $Q$ (which, by construction, contains $\mathrm{E}_{t} C F_{i t} / K_{i, t-1}$ ), the estimated coefficient on real $Q$ would tend toward $\gamma$, and the estimate of the cash-flow coefficient would tend toward zero if realized $C F_{i t}$ were noisy. However, if we estimated equation (11) using long-run real $Q$ - which does not contain forecasts of period $t$ cash flow - we would find that the coefficient on long-run real $Q$ tended toward zero, while that on realized $C F_{i t} / K_{i, t-1}$ would equal $\gamma$. Since we find that the results are virtually identical using real $Q$ and long-run real $Q$, we can reject this interpretation of the data. 
that of real $Q$. However, the coefficients on terminal-value real $Q$ are all statistically significant and we again find no significant cash-flow effects.

In interpreting our results, one could ask whether real $Q$ explains investment well simply because the analysts are privy to inside information about the firm's spending plans. If so, real $Q$ would impound everything that affects the firm's investment, leaving no room for us to find a cash-flow effect even if the firm actually faces liquidity constraints. We think this concern is off the mark for several reasons. First, the analysts are projecting the firm's earnings, not its spending on plant and equipment. The two may be only loosely connected for firms whose capital consists largely of inventories, skilled labor, and the output of R\&D. Second, the instruments we use for the GMM estimates are dated at $t-2$ and earlier. Accordingly, for this critique to be valid, analysts' expectations formed two or more years ago would have to fully characterize investment today. Such omniscience seems extremely unlikely given the inevitable adjustments to investment plans caused by unexpected changes in macroeconomic conditions, the cost of capital, and the behavior of competitors. Finally, to the extent that the analysts are not omniscient - so that there is an error term in the empirical model - the results of the Sargan tests reported in table 5 are germane to the issue at hand. Recall that these tests seldom rejected the joint null hypothesis that the model is correctly specified and that the lagged analysts' forecasts and the current-period investment shock are orthogonal. If the analysts did have substantial knowledge about the firm's actual investment several years in advance, their expectations would be correlated with the error term in the investment equation, and the Sargan test would reject the orthogonality condition.

To summarize our main findings, Tobin's $Q$ is a very noisy indicator of fundamentals; only the part of $Q$ correlated with analysts' earnings expectations or fundamental variables has a sizable effect on investment spending. Real $Q$ and its variants are statistically and economically important determinants of investment. Finally, previous studies that employed $Q$ models may have found significant cash-flow effects either because fundamentals were poorly measured or because lags of Tobin's $Q$ were used as instruments. 


\subsection{Sensitivity Analysis}

We have done more empirical work, which we summarize here, to study the robustness of our results. First, we experimented with alternative liquidity variables (operating income before depreciation and net income) and different assumptions about the timing of the liquidity variable (current year or prior year). Neither affected the results. Second, the empirical results also were unaffected when we included industry fixed effects in equation (11) and when we confined the sample to manufacturing firms. Third, to address whether our results are biased by the dating of the initial I/B/E/S forecasts, we excluded all firm-year observations for which this initial forecast appeared more than two months after the beginning of the firm's fiscal year. Again, this change had no effect on our qualitative results.

We also examined whether our results were affected by different rules for deleting outliers. When we deleted fewer outliers in tax-adjusted Tobin's $Q$ and real $Q$, the GMM estimates of the coefficients on these variables typically were about 20 to 30 percent smaller but still were statistically significant (the coefficients on cash flow remained insignificant). The smaller coefficients reflect the increase in the means of these variables; the implied elasticities of the investment-capital ratio with respect to fundamentals were still above unity. When we deleted fewer outliers in the ratio of investment to beginning-of-period capital the coefficients on fundamentals also decreased somewhat (again, the coefficients on cash flow remained insignificant). The intuition is that, in our sample, investment responds less to fundamentals for higher values of the investment-capital ratio. When we deleted more outliers in cash flow our results were little affected.

The results we report all use simple linear methods to approximate marginal $q$. Given that a growing body of research suggests that this may be a poor specification of the null model, in previous versions of the paper we also explored whether the results change when we allow for more general nonlinear relationships between fundamentals and investment. Our semiparametric regressions indicate that investment does respond nonlinearly to expected fundamentals, with the greatest sensitivity occurring for small values of our proxy to marginal $q$. Nonetheless, the semiparametric results - like those reported above - provide no evidence of liquidity constraints. We tried several different estimation techniques and found that the coefficient on cash 
flow is never statistically different from zero when we use the analysts' forecasts to non-parametrically approximate $Q$.

\subsection{Graphical Presentation of Results}

This subsection presents scatterplots and kernel "smooths" (i.e., nonparametric regression fits) that visually represent the results from our investment equations. The plots demonstrate that the positive correlation between investment and cash flow disappears once we control for fundamentals using real $Q_{i t}$. They also illustrate the magnitude of the nonlinearities present in the data.

Figure 1 plots the relationship between $I_{i t} / K_{i, t-1}$ and $C F_{i t} / K_{i, t-1}$ in our primary (I/B/E/S) sample without performing any controls for future fundamentals. Since the coefficient estimate on tax-adjusted Tobin's $Q$ in most studies is quite close to zero, this scatterplot is roughly representative of the results in the literature (e.g., column 1 of table 2). ${ }^{26}$ The plot and smooth clearly indicate positive correlation between $I / K$ and $C F / K$. However, if cash flow is correlated with the (omitted) measure of fundamentals, the association shown in figure 1 need not represent a liquidity effect. To address this point, figure 2 plots $C F_{i t} / K_{i, t-1}$ from figure 1 against real $Q_{i t}$. The two variables are positively correlated, with the relationship appearing nearly linear. Thus, the identification problem surrounding tests of liquidity effects is not merely theoretical. There is good reason to worry that a positive cash-flow coefficient may simply proxy for the effects of fundamentals.

To complete this line of reasoning, figure 3 plots the residuals of $I_{i t} / K_{i, t-1}$ and $C F_{i t} / K_{i, t-1}$ from nonparametric regressions of each on real $Q_{i t}$ (using normal kernel estimators). That is, this figure plots the component of each variable that is uncorrelated with real $Q$. The relationship portrayed here is far different than in figure 1 . After controlling for our measure of fundamentals, we find no positive correlation between cash flow and investment. Indeed, the distribution of data points is nearly spherical.

Finally, figure 4 is a scatterplot and kernel smooth of the relationship between $I_{i t} / K_{i, t-1}$ and real $Q_{i t}$. The two are highly positively correlated, and the relationship appears to be nonlinear. The concavity in the graph is consistent with the results in Abel

\footnotetext{
${ }^{26}$ The curve shown in this and the subsequent figures is a normal kernel smooth through the data, with the bandwidth set by cross-validation.
} 
and Eberly (1996) and Barnett and Sakellaris (1998). Investment advances almost onefor-one with values of real $Q_{i t}$ below unity, but is not as responsive to real $Q_{i t}$ when $Q$ is very high. This could reflect a true nonlinearity in marginal adjustment costs. Alternatively, the assumptions we used to construct real $Q$ may introduce significant measurement error for higher values of $Q$; perhaps, for example, the firms projected to grow rapidly should have their earnings discounted at an annual rate higher than 10 percent. We leave to future research the analysis of whether the nonlinearity arises from measurement error or from marginal adjustment costs that are not linear in $I / K$.

\subsection{Review of Related Literature}

Our results cast doubt on the robustness of cash-flow effects generated by OLS estimation of investment equations or by GMM estimation with lags of Tobin's $Q$ in the instrument set. To assess the potential scope of our critique, we examined every empirical investment paper cited in Hubbard's (1998) survey of capital-market imperfections and investment, other than those that estimated Euler equations. ${ }^{27}$

Of the eighteen papers that we examined eight reported only OLS estimates of their investment equations [Calomiris and Hubbard (1995); Cantor (1990); Gertler and Hubbard (1988); Hoshi et al. (1991); Kaplan and Zingales (1997); Oliner and Rudebusch (1996); Reiss (1990); and Shin and Stulz (1998)]. Another eight used instrumental variables (IV) techniques but always included Tobin's $Q$ in the instrument set [AlonsoBorrego and Bentolila (1994); Blundell et al. (1992); Devereux and Schiantarelli (1990); Elston (1998); Fazzari et al. (1988); Fazzari and Petersen (1993); Hall (1992); and Hayashi and Inoue (1991).] Thus, sixteen of the eighteen papers are subject to the concerns we have raised about the robustness of cash-flow effects. ${ }^{28}$ Only Schaller (1993) and Schiantarelli and Sembenelli (1996) used IV to estimate an investment-cash flow equation without Tobin's $Q$ in the instrument set. Both obtain significant cash-flow

\footnotetext{
${ }^{27}$ Those papers are not subject to our critique because measures of $Q$ play no role in the estimation. Also, our review omitted two unpublished papers that we could not locate, along with Gilchrist and Himmelberg $(1995,1999)$, whose methodology is expressly intended to circumvent the problems with Tobin's $Q$; however, we do discuss their work below.

${ }^{28}$ To be fair, Blundell et al. (1992) and Devereux and Schiantarelli (1990) did conduct Sargan and $m_{2}$ tests and found little evidence of serial correlation or model misspecification in their preferred specifications. In private correspondence the authors explained that they introduced the lagged dependent variable as an additional regressor in order to alleviate the serial correlation and model rejections. Thus, these authors would have had no reason to be concerned about using lags of Tobin's $Q$ as instruments. Nonetheless, it would be interesting to know if their results are sensitive to removing Tobin's $Q$ from the instrument set.
} 
effects, though we would question the interpretation of Schaller's findings. His control for fundamentals - Tobin's $Q$ - was never significant in his IV results, indicating that the instruments are likely weak (no $F$-tests on the instruments were reported); Schiantarelli and Sembenelli (1996) work with Italian firms that are not publicly traded so they did not construct a $Q$-based control for fundamentals.

The studies that come closest in spirit to dropping Tobin's $Q$ from the instrument set are Gilchrist and Himmelberg $(1995,1999)$. Because both studies use the same basic methodology and obtain similar results, we discuss only the latest one, which represents the frontier of their research. Gilchrist and Himmelberg (1999) employ a VAR procedure to construct "fundamental" $Q$, which they define as a discounted sum of future ratios of either sales to capital, $Y / K$, or operating income to capital, $O I / K$. The VAR used to project $Y / K$ and $O I / K$ includes lags of both variables and a measure of the firm's financial position (either liquid assets or financial working capital minus long-term debt); the variables in this VAR overlap substantially with our "fundamental" instrument set. Gilchrist and Himmelberg then use GMM to estimate a model in which investment depends on the generated "fundamental" $Q$ and a measure of the firm's financial position, also generated from the VAR. They find that "fundamental" $Q$ is an important determinant of investment in their full sample and in most sample splits. Although investment is not sensitive to liquidity for firms with bond ratings, they claim to find evidence of liquidity effects for unrated firms, small firms, and those with low dividend payout rates - the subsamples in which constrained firms arguably predominate.

These results, like ours, indicate that fundamentals are important for investment, but unlike ours, suggest that liquidity matters for some sample splits. However, their results suffer from severe econometric problems. First, the Sargan test rejects the model in virtually every subsample in which Gilchrist and Himmelberg (1999) find evidence of liquidity effects. ${ }^{29}$

Second, and even more damaging, the coefficient that measures liquidity effects in their model is unidentified. They try to estimate three parameters using two regressors. Using our notation, the coefficient on fundamental $Q$ is equal to the inverse of the

\footnotetext{
${ }^{29}$ We could not compare the serial correlation properties of our estimates with theirs because they do not report tests of higher-order serial correlation. Gilchrist and Himmelberg (1995) do not report the Sargan test or any other model diagnostics.
} 
adjustment cost parameter, $1 / \alpha$. The coefficient on liquidity is the product of three variables: (1) $1 / \alpha$; (2) the expected value of the future marginal product of capital (which we will call $\psi$ ), which is, itself, a nonlinear function of technological parameters such as the factor shares and the returns to scale; and (3) a parameter that measures the shadow value of an extra unit of internal finance (which we will call $\gamma$ to be consistent with our notation). Only $\gamma$ is relevant for assessing whether liquidity affects investment, but it cannot be identified from the composite coefficient $(\psi \gamma / \alpha)$ on their financial variable. A relatively large value for this composite coefficient could reflect a greater expected value of the future marginal product of capital, not a difference in the shadow value of internal finance. Accordingly, the empirical results in Gilchrist and Himmelberg (1999) actually provide no information about the presence of liquidity constraints. ${ }^{30}$

The identification problem in Gilchrist and Himmelberg (1999) illustrates a general difficulty in testing for liquidity constraints. As we noted earlier, Kaplan and Zingales (1997) and Chirinko (1997) both show that the size of the cash-flow coefficient does not measure the extent of liquidity constraints per se. This coefficient will reflect a mixture of technological parameters and parameters that measure the shadow value of internal net worth. This mixing is inevitable, as the firm's response to a change in its financial position will depend on the technology it uses. To disentangle these parameters, one must develop a structural model that specifies the form of the potential liquidity constraint and must ensure that the key liquidity parameters can be identified econometrically. Gilchrist and Himmelberg (1999) do not meet the second requirement.

In this paper, we have not written down a structural model that embeds liquidity constraints, and thus would face the same problems of interpretation had we found any consistently significant cash-flow effects. However, we found the opposite - that cash flow does not matter once one controls properly for fundamentals. This negative result allows us to reject an unspecified model with liquidity constraints in favor of the basic neoclassical model.

\footnotetext{
${ }^{30}$ We can compare the magnitude of the liquidity effect across sample splits if we assume - for the sake of argument - that the expected value of the future marginal product of capital is fixed across their sample. With this assumption, we then multiplied the reported coefficient $(\psi \gamma / \alpha)$ on their liquidity variable by $\alpha$. In the dividend split, this implies a smaller estimate of $\gamma$ for the low-dividend firms than for the supposedly unconstrained high-payout firms. For the firm-size and bond-rating splits, the estimate of $\gamma$ for small firms exceeds that for large firms, although just barely in some cases. Even so the difference is much less than what Gilchrist and Himmelberg report based on the composite parameter. This exercise, however, cannot address the key question of whether $\gamma$ would be statistically significant if it could be estimated.
} 


\subsection{Aggregate Implications}

As noted in the introduction, the revival of the liquidity literature stemmed, in part, from the perceived failure of neoclassical fundamentals to explain the aggregate timeseries behavior of investment. As a case in point, figure 5 plots the relationship between aggregate $I_{t} / K_{t-1}$ and Tobin's $Q_{t}$ in levels and percent changes from 1984 through 1995. We construct aggregate $I_{t} / K_{t-1}$ as a weighted average of the firm-level $I_{i t} / K_{i, t-1}$ values in our primary sample, with $K_{i, t-1} / \sum_{i} K_{i, t-1}$ serving as the firm-specific weight; aggregate Tobin's $Q$ is constructed with the same weights. Clearly, the relationship between these series is not consistent with neoclassical theory. Both the levels (the top panel) and the percent changes (the bottom panel) diverge substantially from one another, and the correlation between the percent changes is actually negative.

Given the robust finding in our micro data that real $Q_{i t}$ helps predict investment, we investigate whether aggregated real $Q_{t}$ better predicts the time-series fluctuations of investment. Figure 6 plots the aggregate investment-capital ratio against an aggregate real $Q_{t}$ variable, which is constructed by taking the capital-stock weighted average of the firm-level real $Q_{i t}$ in each year. As is evident from the figure, this measure of fundamentals is much more highly correlated with investment, both in levels and percent changes. Aggregate investment and real $Q$ clearly move in sync over the two expansions and one recession in this sample period. To our knowledge, this is the first demonstration of a strong time-series link between investment and a forward-looking neoclassical variable.

\section{Conclusion}

Our results suggest that the neoclassical model of investment behavior fits well at the firm level, confirming previous, more restrictive, studies by Cummins et al. (1994, 1995). In contrast to those studies, however, we show that neoclassical fundamentals matter outside of selected periods with natural experiments. Furthermore, we find that our simple measure of fundamentals describes the movements in aggregate investment over the business cycle.

Complementing these results, we find no evidence that liquidity constraints affect investment for US companies that are mature enough to have issued public equity. This 
result conflicts with the significant liquidity effects found in many previous studies that have estimated investment-cash flow regressions. However, we show that those results may not be robust, as they appear to hinge on the use of Tobin's $Q$ as the control for fundamentals or as an instrument in GMM estimation. In our regressions, cash-flow effects disappear altogether when we proxy for fundamentals with analysts' earnings expectations or when we remove Tobin's $Q$ from the instrument set. These departures from the standard methodology strike us as appropriate given widespread concerns that Tobin's $Q$ is a noisy proxy for fundamentals and that it may contain serially correlated measurement error.

As noted in the introduction, this paper fits into a growing literature that has questioned the existing evidence of liquidity constraints on investment. In our view, the case for such constraints is not nearly as strong as many seem to believe. While investment may actually be constrained for certain classes of firms - especially those that have yet to issue public securities - it is premature to embrace this assertion as fact.

Looking ahead, we see considerable value to a study that would critically assess the evidence for liquidity constraints from papers that have estimated Euler equations. This technique does not rely on Tobin's $Q$, and thus is immune to the critique in our paper. However, our own experience with Euler equations suggests that the results can be quite sensitive to how the model is specified, the choice of instrument set, and other judgmental aspects of the estimation. It is essential to know whether the results in the literature are reliable. 


\section{A Construction of Tax-Adjusted Tobin's $Q$}

Tax-adjusted Tobin's $Q$ is defined as:

$$
Q_{i t}=\frac{1}{\left(1-\tau_{t}\right)}\left[\left(\frac{L_{i t} V_{i t}+B_{i t}-A_{i t}}{K_{i, t-1}}\right)-p_{t}\left(1-\Gamma_{i t}\right)\right]
$$

where $\tau$ is the marginal corporate tax rate; $L$ is an indicator variable equaling unity if the firm is not paying dividends and $\left(1-m_{t}\right) /\left(1-z_{t}\right)$ if the firm is paying dividends, where $m$ is the personal tax rate on dividends and $z$ is an accrual-equivalent capital gains tax rate; $V$ is the market value of the firm's equity; $B$ is the book value of its outstanding debt; $A$ is the present value of the depreciation allowances on investment made before period $t$; $K$ is the replacement value of the firm's capital stock including inventories; $p$ is the price of capital goods relative to the price of output; and $\Gamma$ is the present value of the tax benefit for each dollar of current investment spending. For example, with an investment tax credit at rate $k, \Gamma$ is:

$$
\Gamma_{i t}=k_{i t}+\sum_{s=t}^{\infty}\left(1+r_{s}+\pi_{s}^{e}\right)^{s-t} \tau_{s} D E P_{i s}(s-t)
$$

where $r$ is the default-risk-free real interest rate (assumed to equal 3 percent), $\pi^{e}$ is the expected inflation rate, and $D E P_{i s}(a)$ is the depreciation allowance permitted for an asset of age $a$.

Unless noted otherwise, we constructed each component of $Q_{i t}$ from Compustat data. We measure the firm's market value of equity as the sum of the market value of common equity (defined as the number of common shares outstanding multiplied by the end-of-year common stock price) and the market value of preferred stock (defined as the firm's preferred dividend payout divided by S\&P's preferred dividend yield obtained from Citibase). The value of firm debt is the sum of short-term debt and long-term debt, both measured at book value. The replacement value of the capital stock is calculated from the standard perpetual inventory method with a firm-level rate of economic depreciation constructed using the method in Cummins et al. (1994). The replacement value of inventories is also constructed using the perpetual inventory method. 
Among the remaining components of tax-adjusted $Q$, the data on expected inflation are the annual averages of the monthly expectations in the Livingston Survey, which is administered by the Federal Reserve Bank of Philadelphia. The tax parameters $(\tau, m$, $z, A, k$, and $D E P$ ) are updated from those used in Cummins et al. (1994); we construct firm-specific investment tax credits and depreciation allowances to reflect the asset composition of the firm's two-digit SIC code.

The firm-level data were modified according to the following rules. If the firm's estimated depreciation rate was negative or greater than unity, we set it equal to the mean for firms in the same two-digit SIC code. If the replacement value of the capital stock or inventory was negative, we set it equal to book value. If dividend payouts on preferred stock were reported as missing, we set them equal to zero. Finally, if no inventory valuation method was specified on Compustat, we assume the firm used the first-in-first-out (FIFO) system; if multiple valuation methods were reported, we used the one listed as the primary method. 


\section{References}

Abel, Andrew B. and Olivier J. Blanchard (1986). The present value of profits and cyclical movements in investment. Econometrica 54(2): 249-273.

Abel, Andrew B. and Janice C. Eberly (1996). Investment and $q$ with fixed costs: An empirical analysis. Mimeograph, University of Pennsylvania.

Alonso-Borrego, Cesar and Samuel Bentolila (1994). Investment and $Q$ in Spanish manufacturing firms. Oxford Bulletin of Economics and Statistics 56(1): 49-65.

Arellano, Manuel and Stephen Bond (1991). Some tests of specification for panel data: Monte carlo evidence and an application to employment equations. Review of Economic Studies 58(2): 277-297.

Barnett, Steven A. and Plutarchos Sakellaris (1998). Non-linear response of firm investment to $q$ : Testing a model of convex and non-convex adjustment costs. Journal of Monetary Economics 42(2): 261-80.

Bernanke, Ben S., Henning Bohn, and Peter C. Reiss (1988). Alternative non-nested specification tests of time-series investment models. Journal of Econometrics 37(3): 293-326.

Blundell, Richard, Stephen Bond, Michael Devereux, and Fabio Schiantarelli (1992). Investment and Tobin's q: Evidence from company panel data. Journal of Econometrics 51(1/2): 233-258.

Brealey, Richard A. and Stewart C. Myers (1996). Principles of Corporate Finance (5th ed.). New York: McGraw-Hill.

Brown, Lawrence D. (1993). Earnings forecast research: Its implications for capital markets research. International Journal of Forecasting 9(2): 295-320.

Brown, Lawrence D. (1996a). Analyst forecasting errors and their implications for security analysis: An alternative perspective. Financial Analysts' Journal 1996(January/February): 40-47.

Brown, Lawrence D. (1996b). I/B/E/S Research Bibliography (Fifth ed.). New York: $\mathrm{I} / \mathrm{B} / \mathrm{E} / \mathrm{S}$ International Inc.

Caballero, Ricardo J. (1997). Aggregate investment: A 90's view. Mimeograph, MIT.

Caballero, Ricardo J., Eduardo Engel, and John C. Haltiwanger (1995). Plant-level adjustment dynamics and aggregate investment dynamics. Brookings Papers on Economic Activity 1995(2): 1-54.

Caballero, Ricardo J. and John V. Leahy (1996). Fixed costs: The demise of marginal $q$. NBER Working Paper No. 5508.

Calomiris, Charles W. and R. Glenn Hubbard (1995). Internal finance and firm-level investment: Evidence from the undistributed profits tax of 1937-1938. Journal of Business 68(4): 443-82.

Cantor, Richard (1990). Effects of leverage on corporate investment and hiring decisions. Federal Reserve Bank of New York Quarterly Review 15(2): 31-41.

Chirinko, Robert S. (1993). Business fixed investment spending: A critical survey of modeling strategies, empirical results, and policy implications. Journal of Economic Literature 31(4): 1875-1911.

Chirinko, Robert S. (1997). Finance constraints, liquidity, and investment spending: Theoretical restrictions and international evidence. Journal of the Japanese and International Economies 11(2): 185-207.

Cleary, Sean (1999). The relationship between firm investment and financial status. Journal of Finance 54(2): 673-92. 
Coggin, T. Daniel (1990). The analyst and the investment process. In F. J. Fabozzi (Ed.), Managing Institutional Assets, pp. 105-18. New York: Harper \& Row.

Cummins, Jason G. and Kevin A. Hassett (1992). The effects of taxation on investment: New evidence from firm-level panel data. National Tax Journal 45(3): 243-252.

Cummins, Jason G., Kevin A. Hassett, and R. Glenn Hubbard (1994). A reconsideration of investment behavior using tax reforms as natural experiments. Brookings Papers on Economic Activity 1994(2): 1-74.

Cummins, Jason G., Kevin A. Hassett, and R. Glenn Hubbard (1995). Tax reforms and investment: A cross-country comparison. Journal of Public Economics 62: 237-73.

Devereux, Michael and Fabio Schiantarelli (1990). Investment, financial factors, and cash flow: Evidence from U.K. panel data. In R. G. Hubbard (Ed.), Asymmetric Information, Corporate Finance, and Investment. Chicago: University of Chicago Press.

Elston, Julie Ann (1998). Investment, liquidity constraints and bank relationships: Evidence from German manufacturing firms. In S. W. Black and M. Moersch (Eds.), Competition and convergence in financial markets: The German and Anglo-American Models. Elsevier: Amsterdam.

Erickson, Timothy and Toni M. Whited (1998). Measurement error and the relationship between investment and $Q$. Mimeograph, Bureau of Labor Statistics.

Fazzari, Steven M., R. Glenn Hubbard, and Bruce C. Petersen (1988). Financing constraints and corporate investment. Brookings Papers on Economic Activity 1988(1): 141-95.

Fazzari, Steven M., R. Glenn Hubbard, and Bruce C. Petersen (1996). Financing constraints and corporate investment: Comment on Kaplan and Zingales. NBER Working Paper No. 5462.

Fazzari, Steven M. and Bruce C. Petersen (1993). Working capital and fixed investment: New evidence on financing constraints. RAND Journal of Economics 24(3): 328-42.

Gertler, Mark and R. Glenn Hubbard (1988). Financial factors in business fluctuations. In Financial Market Volatility. Kansas City: Federal Reserve Bank of Kansas City.

Gilchrist, Simon and Charles P. Himmelberg (1995). Evidence on the role of cash flow for investment. Journal of Monetary Economics 36(3): 541-72.

Gilchrist, Simon and Charles P. Himmelberg (1999). Investment, fundamentals, and finance. In B. S. Bernanke and J. J. Rotemberg (Eds.), NBER Macroeconomics Annual, pp. 223-62. Cambridge: MIT Press.

Givoly, Dan and Josef Lakonishok (1984). Properties of analysts' forecasts of earnings: A review and analysis of the research. Journal of Accounting Literature 3(1): 117-52.

Hall, Bronwyn H. (1992). Investment and research and development at the firm level: Does the source of financing matter? NBER Working Paper No. 4096.

Hassett, Kevin A. and R. Glenn Hubbard (1997). Tax policy and business fixed investment. In A. J. Auerbach (Ed.), Fiscal Policy: Lessons from Economic Research. Cambridge: MIT Press.

Hayashi, Fumio (1982). Tobin's marginal $q$ and average $Q$ : A neoclassical interpretation. Econometrica 50(1): 213-224.

Hayashi, Fumio (1997). The main bank system and corporate investment: An empirical reassessment. NBER Working Paper No. 6172.

Hayashi, Fumio and Tohru Inoue (1991). The relation between firm growth and $Q$ with multiple capital goods: Theory and evidence from panel data on Japanese firms. Econometrica 59(3): 731-753. 
Hoshi, Takeo, Anil K. Kashyap, and David Scharfstein (1991). Corporate capital structure, liquidity and investment: Evidence from Japanese industrial groups. Quarterly Journal of Economics 106(1): 33-60.

Hubbard, R. Glenn (1998). Capital-market imperfections and investment. Journal of Economic Literature 36(1): 193-225.

Kaplan, Steven N. and Luigi Zingales (1997). Do investment-cash flow sensitivities provide useful measures of financing constraints? Quarterly Journal of Economics 112(1): 169-215.

Keane, Michael P. and David E. Runkle (1998). Are financial analysts' forecasts of corporate profits rational? Journal of Political Economy 106(4): 768-88.

Oliner, Stephen D. and Glenn D. Rudebusch (1996). Is there a broad credit channel of monetary policy? Federal Reserve Bank of San Francisco Economic Review 1(1): 3-13.

Reiss, Peter C. (1990). Economic and financial determinants of oil and gas exploration activity. In R. G. Hubbard (Ed.), Asymmetric Information, Corporate Finance, and Investment. Chicago: University of Chicago Press.

Schaller, Huntley (1993). Asymmetric information, liquidity constraints and Canadian investment. Canadian Journal of Economics 26(3): 552-74.

Schiantarelli, Fabio and Alessandro Sembenelli (1996). Form of ownership and financial constraints: Panel data evidence from leverage and investment equations. World Bank Working Paper \# 1629.

Shiller, Robert J. (1989). Market Volatility. Cambridge: MIT Press.

Shin, Hyun-Han and Rene Stulz (1998). Are internal capital markets efficient? Quarterly Journal of Economics 113(2): 531-52.

Summers, Lawrence H. (1981). Taxation and corporate investment: A $q$-theory approach. Brookings Papers on Economic Activity 1981(1): 67-127.

Whited, Toni M. (1999). Is it inefficient investment that causes the diversification discount? Mimeograph, University of Maryland. 
Table 1: Means, Medians, and Standard Deviations of Variables in Compustat and I/B/E/S Samples

\begin{tabular}{|c|c|c|c|c|c|c|c|c|c|c|}
\hline \multirow[b]{2}{*}{ Variable } & \multicolumn{2}{|c|}{ All Firms } & \multicolumn{2}{|c|}{ Dividend } & \multicolumn{2}{|c|}{ No Dividend } & \multicolumn{2}{|c|}{ Bond Rating } & \multicolumn{2}{|c|}{ No Bond Rating } \\
\hline & $\begin{array}{l}\text { Compustat } \\
\text { (1) }\end{array}$ & $\begin{array}{c}\mathrm{I} / \mathrm{B} / \mathrm{E} / \mathrm{S} \\
(2)\end{array}$ & $\begin{array}{l}\text { Compustat } \\
\text { (3) }\end{array}$ & $\begin{array}{c}\mathrm{I} / \mathrm{B} / \mathrm{E} / \mathrm{S} \\
(4)\end{array}$ & $\begin{array}{l}\text { Compustat } \\
\text { (5) }\end{array}$ & $\begin{array}{c}\mathrm{I} / \mathrm{B} / \mathrm{E} / \mathrm{S} \\
(6)\end{array}$ & $\begin{array}{l}\text { Compustat } \\
\text { (7) }\end{array}$ & $\begin{array}{c}\mathrm{I} / \mathrm{B} / \mathrm{E} / \mathrm{S} \\
(8)\end{array}$ & $\begin{array}{l}\text { Compustat } \\
\text { (9) }\end{array}$ & $\begin{array}{c}\mathrm{I} / \mathrm{B} / \mathrm{E} / \mathrm{S} \\
(10)\end{array}$ \\
\hline$I_{i t} / K_{i, t-1}$ & $\begin{array}{c}0.294 \\
(0.257) \\
{[0.176]}\end{array}$ & $\begin{array}{c}0.296 \\
(0.260) \\
{[0.169]}\end{array}$ & $\begin{array}{c}0.282 \\
(0.248) \\
{[0.163]}\end{array}$ & $\begin{array}{c}0.283 \\
(0.250) \\
{[0.159]}\end{array}$ & $\begin{array}{c}0.329 \\
(0.291) \\
{[0.202]}\end{array}$ & $\begin{array}{c}0.349 \\
(0.316) \\
{[0.199]}\end{array}$ & $\begin{array}{c}0.266 \\
(0.236) \\
{[0.154]}\end{array}$ & $\begin{array}{c}0.268 \\
(0.239) \\
{[0.151]}\end{array}$ & $\begin{array}{c}0.314 \\
(0.274) \\
{[0.187]}\end{array}$ & $\begin{array}{c}0.322 \\
(0.285) \\
{[0.181]}\end{array}$ \\
\hline Tobin's $Q_{i t}$ & $\begin{array}{c}3.879 \\
(2.369) \\
{[4.374]}\end{array}$ & $\begin{array}{c}4.155 \\
(2.604) \\
{[4.498]}\end{array}$ & $\begin{array}{c}3.886 \\
(2.444) \\
{[4.240]}\end{array}$ & $\begin{array}{c}4.088 \\
(2.607) \\
{[4.329]}\end{array}$ & $\begin{array}{l}3.862 \\
(2.182) \\
{[4.722]}\end{array}$ & $\begin{array}{c}4.433 \\
(2.588) \\
{[5.128]}\end{array}$ & $\begin{array}{c}3.241 \\
(2.047) \\
{[3.531]}\end{array}$ & $\begin{array}{c}3.359 \\
(2.174) \\
{[3.546]}\end{array}$ & $\begin{array}{c}4.335 \\
(2.663) \\
{[4.836]}\end{array}$ & $\begin{array}{c}4.920 \\
(3.136) \\
{[5.137]}\end{array}$ \\
\hline Real $Q_{i t}$ & - & $\begin{array}{c}1.454 \\
(0.979) \\
{[1.581]}\end{array}$ & - & $\begin{array}{c}1.349 \\
(0.913) \\
{[1.474]}\end{array}$ & - & $\begin{array}{c}1.888 \\
(1.244) \\
{[1.901]}\end{array}$ & - & $\begin{array}{c}1.089 \\
(0.737) \\
{[1.194]}\end{array}$ & - & $\begin{array}{c}1.805 \\
(1.283) \\
{[1.812]}\end{array}$ \\
\hline$C F_{i t} / K_{i, t-1}$ & $\begin{array}{c}0.408 \\
(0.325) \\
{[0.391]}\end{array}$ & $\begin{array}{c}0.427 \\
(0.337) \\
{[0.372]}\end{array}$ & $\begin{array}{c}0.412 \\
(0.322) \\
{[0.361]}\end{array}$ & $\begin{array}{c}0.418 \\
(0.328) \\
{[0.356]}\end{array}$ & $\begin{array}{c}0.397 \\
(0.333) \\
{[0.463]}\end{array}$ & $\begin{array}{c}0.463 \\
(0.371) \\
{[0.431]}\end{array}$ & $\begin{array}{c}0.329 \\
(0.256) \\
{[0.314]}\end{array}$ & $\begin{array}{c}0.352 \\
(0.274) \\
{[0.306]}\end{array}$ & $\begin{array}{c}0.464 \\
(0.383) \\
{[0.429]}\end{array}$ & $\begin{array}{c}0.499 \\
(0.409) \\
{[0.414]}\end{array}$ \\
\hline Sales & $\begin{array}{l}2614 \\
(510) \\
{[7625]}\end{array}$ & $\begin{array}{c}3128 \\
(764) \\
{[8353]}\end{array}$ & $\begin{array}{c}3302 \\
(762) \\
{[8664]}\end{array}$ & $\begin{array}{c}3635 \\
(1001) \\
{[9107]}\end{array}$ & $\begin{array}{c}730 \\
(153) \\
{[2647]}\end{array}$ & $\begin{array}{l}1037 \\
(241) \\
{[3169]}\end{array}$ & $\begin{array}{c}4933 \\
(1742) \\
{[10705]}\end{array}$ & $\begin{array}{c}5173 \\
(1929) \\
{[10976]}\end{array}$ & $\begin{array}{c}959 \\
(252) \\
{[3361]}\end{array}$ & $\begin{array}{c}1162 \\
(361) \\
{[3628]}\end{array}$ \\
\hline Sales Growth & $\begin{array}{c}0.064 \\
(0.044) \\
{[0.220]}\end{array}$ & $\begin{array}{c}0.062 \\
(0.044) \\
{[0.158]}\end{array}$ & $\begin{array}{c}0.047 \\
(0.037) \\
{[0.143]}\end{array}$ & $\begin{array}{c}0.047 \\
(0.037) \\
{[0.132]}\end{array}$ & $\begin{array}{c}0.110 \\
(0.077) \\
{[0.350]}\end{array}$ & $\begin{array}{c}0.124 \\
(0.094) \\
{[0.228]}\end{array}$ & $\begin{array}{c}0.045 \\
(0.032) \\
{[0.169]}\end{array}$ & $\begin{array}{c}0.044 \\
(0.031) \\
{[0.150]}\end{array}$ & $\begin{array}{c}0.077 \\
(0.055) \\
{[0.250]}\end{array}$ & $\begin{array}{c}0.079 \\
(0.060) \\
{[0.163]}\end{array}$ \\
\hline Observations & 11857 & 8773 & 8685 & 7061 & 3172 & 1712 & 4937 & 4300 & 6920 & 4473 \\
\hline
\end{tabular}

The medians of variables are in parentheses below the means. The standard deviations of variables are in square brackets below the means.

$I_{i t} / K_{i, t-1}$ is the ratio of investment to beginning-of-period capital. The construction of tax-adjusted Tobin's $Q_{i t}$ and real $Q_{i t}$ is discussed in the text. $C F_{i t} / K_{i, t-1}$ is the ratio of cash flow (the sum of net income and current depreciation) to beginning-of-period capital. Sales is in millions of 1992 dollars.

The sample period is 1984-95. The Compustat sample contains the firms with at least four years of complete Compustat data. The I/B/E/S sample contains the firms with at least four years of complete Compustat and I/B/E/S data. The "dividend" and "no dividend" samples contain firms that did and did not pay dividends in the prior year. The "bond rating" and "no bond rating" samples contain firms that are rated and not rated by Standard \& Poor's at the beginning of the year. 
Table 2: OLS Estimates of First Differenced Investment Equations

\begin{tabular}{|c|c|c|c|c|c|}
\hline Parameter & $\begin{array}{l}\text { All Firms } \\
\text { (1) }\end{array}$ & $\begin{array}{l}\text { Dividend } \\
\text { (2) }\end{array}$ & $\begin{array}{l}\text { No Dividend } \\
\text { (3) }\end{array}$ & $\begin{array}{l}\text { Bond Rating } \\
\text { (4) }\end{array}$ & $\begin{array}{l}\text { No Bond Rating } \\
\text { (5) }\end{array}$ \\
\hline & \multicolumn{5}{|c|}{ COMPUSTAT SAMPLE } \\
\hline Tobin's $Q_{i t}$ & $\begin{array}{c}0.016 \\
(0.002)\end{array}$ & $\begin{array}{c}0.016 \\
(0.002)\end{array}$ & $\begin{array}{c}0.013 \\
(0.003)\end{array}$ & $\begin{array}{c}0.029 \\
(0.004)\end{array}$ & $\begin{array}{c}0.012 \\
(0.002)\end{array}$ \\
\hline$C F_{i t} / K_{i, t-1}$ & $\begin{array}{c}0.152 \\
(0.014)\end{array}$ & $\begin{array}{c}0.189 \\
(0.022)\end{array}$ & $\begin{array}{c}0.118 \\
(0.021)\end{array}$ & $\begin{array}{l}0.106 \\
(0.024)\end{array}$ & $\begin{array}{c}0.174 \\
(0.017)\end{array}$ \\
\hline $\begin{array}{l}R^{2} \\
m_{2} p \text {-value }\end{array}$ & $\begin{array}{l}0.099 \\
0.000\end{array}$ & $\begin{array}{l}0.115 \\
0.001\end{array}$ & $\begin{array}{l}0.079 \\
0.002\end{array}$ & $\begin{array}{l}0.122 \\
0.000\end{array}$ & $\begin{array}{l}0.101 \\
0.000\end{array}$ \\
\hline \multirow[t]{2}{*}{ Observations } & $\begin{array}{l}1361 \\
7162\end{array}$ & $\begin{array}{c}890 \\
5029\end{array}$ & $\begin{array}{c}414 \\
1383\end{array}$ & $\begin{array}{c}486 \\
2773\end{array}$ & $\begin{array}{c}847 \\
3655\end{array}$ \\
\hline & \multicolumn{5}{|c|}{ I/B/E/S SAMPLE } \\
\hline Tobin's $Q_{i t}$ & $\begin{array}{c}0.015 \\
(0.002)\end{array}$ & $\begin{array}{c}0.018 \\
(0.003)\end{array}$ & $\begin{array}{c}0.011 \\
(0.004)\end{array}$ & $\begin{array}{c}0.025 \\
(0.004)\end{array}$ & $\begin{array}{c}0.010 \\
(0.002)\end{array}$ \\
\hline$C F_{i t} / K_{i, t-1}$ & $\begin{array}{c}0.171 \\
(0.019)\end{array}$ & $\begin{array}{c}0.190 \\
(0.043)\end{array}$ & $\begin{array}{l}0.117 \\
(0.032)\end{array}$ & $\begin{array}{l}0.160 \\
(0.029)\end{array}$ & $\begin{array}{c}0.202 \\
(0.024)\end{array}$ \\
\hline $\begin{array}{l}R^{2} \\
m_{2} p \text {-value }\end{array}$ & $\begin{array}{l}0.102 \\
0.004\end{array}$ & $\begin{array}{l}0.112 \\
0.175\end{array}$ & $\begin{array}{l}0.067 \\
0.264\end{array}$ & $\begin{array}{l}0.004 \\
0.094\end{array}$ & $\begin{array}{l}0.101 \\
0.094\end{array}$ \\
\hline \multirow[t]{2}{*}{ Observations } & $\begin{array}{l}1018 \\
5296\end{array}$ & $\begin{array}{c}754 \\
4235\end{array}$ & $\begin{array}{l}219 \\
668\end{array}$ & $\begin{array}{c}427 \\
2638\end{array}$ & $\begin{array}{c}567 \\
2260\end{array}$ \\
\hline & \multicolumn{5}{|c|}{ I/B/E/S SAMPLE } \\
\hline Real $Q_{i t}$ & $\begin{array}{c}0.080 \\
(0.007)\end{array}$ & $\begin{array}{c}0.098 \\
(0.021)\end{array}$ & $\begin{array}{c}0.063 \\
(0.017)\end{array}$ & $\begin{array}{c}0.142 \\
(0.037)\end{array}$ & $\begin{array}{c}0.043 \\
(0.010)\end{array}$ \\
\hline$C F_{i t} / K_{i, t-1}$ & $\begin{array}{c}0.033 \\
(0.014)\end{array}$ & $\begin{array}{c}0.057 \\
(0.063)\end{array}$ & $\begin{array}{c}0.015 \\
(0.024)\end{array}$ & $\begin{array}{c}0.015 \\
(0.081)\end{array}$ & $\begin{array}{c}0.054 \\
(0.021)\end{array}$ \\
\hline $\begin{array}{l}R^{2} \\
m_{2} p \text {-value }\end{array}$ & $\begin{array}{l}0.129 \\
0.000\end{array}$ & $\begin{array}{l}0.133 \\
0.619\end{array}$ & $\begin{array}{l}0.113 \\
0.361\end{array}$ & $\begin{array}{l}0.171 \\
0.007\end{array}$ & $\begin{array}{l}0.094 \\
0.121\end{array}$ \\
\hline $\begin{array}{l}\text { Firms } \\
\text { Observations }\end{array}$ & $\begin{array}{l}1018 \\
5296\end{array}$ & $\begin{array}{c}754 \\
4235\end{array}$ & $\begin{array}{l}219 \\
668\end{array}$ & $\begin{array}{c}427 \\
2638\end{array}$ & $\begin{array}{c}567 \\
2260\end{array}$ \\
\hline
\end{tabular}

The dependent variable is the first difference of the ratio of investment to beginning-of-period capital, $I_{i t} / K_{i, t-1}$. The regressors are the first differences of tax-adjusted Tobin's $Q_{i t}$, real $Q_{i t}$ constructed using $\mathrm{I} / \mathrm{B} / \mathrm{E} / \mathrm{S}$ analysts' beginning-of-period forecasts, and the ratio of cash flow to beginning-of-period capital, $C F_{i t} / K_{i, t-1}$. Year dummies and an intercept are included (but not reported) in all regressions. Robust standard errors on coefficients are in parentheses.

The estimation period is 1988-95. The sample in the first panel contains the firms with at least four years of complete Compustat data. The sample in the second and third panels contains the firms with at least four years of complete Compustat and I/B/E/S data. The "dividend" and "no dividend" samples contain firms that did and did not pay dividends in the prior year. The "bond rating" and "no bond rating" samples contain firms that are rated and not rated by Standard \& Poor's at the beginning of the year.

The estimation period and samples are identical to those for the GMM estimates reported in tables 3-6.

The $m_{2}$ statistic is a test for second-order serial correlation in the residuals, asymptotically distributed as $\mathrm{N}(0,1)$ under the null of no serial correlation. 
Table 3: GMM Estimates of First Differenced Investment Equations: Comparing Instrument Sets Containing Tobin's $Q$ and “Fundamental” Variables (I/B/E/S Sample)

\begin{tabular}{|c|c|c|c|c|c|c|c|c|c|c|}
\hline \multirow[t]{2}{*}{ Parameter } & \multicolumn{2}{|c|}{ All Firms } & \multicolumn{2}{|c|}{ Dividend } & \multicolumn{2}{|c|}{ No Dividend } & \multicolumn{2}{|c|}{ Bond Rating } & \multicolumn{2}{|c|}{ No Bond Rating } \\
\hline & (1) & (2) & (3) & (4) & (5) & (6) & (7) & (8) & & (10) \\
\hline & \multicolumn{10}{|c|}{ INSTRUMENT SET WITH TOBIN'S $Q$} \\
\hline Tobin's $Q_{i t}$ & $\begin{array}{c}0.010 \\
(0.008)\end{array}$ & - & $\begin{array}{c}0.001 \\
(0.010)\end{array}$ & - & $\begin{array}{l}-0.015 \\
(0.044)\end{array}$ & - & $\begin{array}{c}0.014 \\
(0.011)\end{array}$ & - & $\begin{array}{l}-0.000 \\
(0.012)\end{array}$ & - \\
\hline Real $Q_{i t}$ & - & $\begin{array}{c}0.156 \\
(0.068)\end{array}$ & - & $\begin{array}{c}0.038 \\
(0.086)\end{array}$ & - & $\begin{array}{c}0.103 \\
(0.041)\end{array}$ & - & $\begin{array}{c}0.255 \\
(0.113)\end{array}$ & - & $\begin{array}{c}0.175 \\
(0.085)\end{array}$ \\
\hline$C F_{i t} / K_{i, t-1}$ & $\begin{array}{c}0.229 \\
(0.060)\end{array}$ & $\begin{array}{l}-0.153 \\
(0.199)\end{array}$ & $\begin{array}{c}0.253 \\
(0.094)\end{array}$ & $\begin{array}{l}0.124 \\
(0.279)\end{array}$ & $\begin{array}{c}0.378 \\
(0.203)\end{array}$ & $\begin{array}{c}0.037 \\
(0.151)\end{array}$ & $\begin{array}{c}0.241 \\
(0.100)\end{array}$ & $\begin{array}{l}-0.362 \\
(0.355)\end{array}$ & $\begin{array}{c}0.243 \\
(0.093)\end{array}$ & $\begin{array}{l}-0.235 \\
(0.262)\end{array}$ \\
\hline \multirow[t]{2}{*}{$\begin{array}{l}\text { Sargan } p \text {-value } \\
m_{2} p \text {-value }\end{array}$} & $\begin{array}{l}0.000 \\
0.005\end{array}$ & $\begin{array}{l}0.000 \\
0.058\end{array}$ & $\begin{array}{l}0.000 \\
0.131\end{array}$ & $\begin{array}{l}0.000 \\
0.493\end{array}$ & $\begin{array}{l}0.032 \\
0.216\end{array}$ & $\begin{array}{l}0.010 \\
0.712\end{array}$ & $\begin{array}{l}0.002 \\
0.012\end{array}$ & $\begin{array}{l}0.064 \\
0.013\end{array}$ & $\begin{array}{l}0.000 \\
0.079\end{array}$ & $\begin{array}{l}0.005 \\
0.790\end{array}$ \\
\hline & \multicolumn{10}{|c|}{ INSTRUMENT SET WITH “FunDAMENTAL” VARIABLES } \\
\hline Tobin's $Q_{i t}$ & $\begin{array}{c}0.148 \\
(0.063)\end{array}$ & - & $\begin{array}{c}0.190 \\
(0.081)\end{array}$ & - & $\begin{array}{c}0.160 \\
(0.064)\end{array}$ & - & $\begin{array}{c}0.172 \\
(0.058)\end{array}$ & - & $\begin{array}{c}0.067 \\
(0.046)\end{array}$ & - \\
\hline Real $Q_{i t}$ & - & $\begin{array}{c}0.459 \\
(0.153)\end{array}$ & - & $\begin{array}{c}0.459 \\
(0.198)\end{array}$ & - & $\begin{array}{c}0.443 \\
(0.144)\end{array}$ & - & $\begin{array}{c}0.436 \\
(0.231)\end{array}$ & - & $\begin{array}{c}0.318 \\
(0.097)\end{array}$ \\
\hline$C F_{i t} / K_{i, t-1}$ & $\begin{array}{l}-0.053 \\
(0.304)\end{array}$ & $\begin{array}{l}-0.452 \\
(0.447)\end{array}$ & $\begin{array}{l}-0.124 \\
(0.320)\end{array}$ & $\begin{array}{l}-0.405 \\
(0.598)\end{array}$ & $\begin{array}{l}-0.319 \\
(0.405)\end{array}$ & $\begin{array}{l}-0.990 \\
(0.566)\end{array}$ & $\begin{array}{l}0.246 \\
(0.438)\end{array}$ & $\begin{array}{l}-0.699 \\
(0.715)\end{array}$ & $\begin{array}{l}-0.062 \\
(0.221)\end{array}$ & $\begin{array}{l}-0.697 \\
(0.309)\end{array}$ \\
\hline $\begin{array}{l}\text { Sargan } p \text {-value } \\
m_{2} p \text {-value }\end{array}$ & $\begin{array}{l}0.032 \\
0.041\end{array}$ & $\begin{array}{l}0.072 \\
0.106\end{array}$ & $\begin{array}{l}0.454 \\
0.273\end{array}$ & $\begin{array}{l}0.177 \\
0.785\end{array}$ & $\begin{array}{l}0.071 \\
0.630\end{array}$ & $\begin{array}{l}0.958 \\
0.863\end{array}$ & $\begin{array}{l}0.871 \\
0.217\end{array}$ & $\begin{array}{l}0.192 \\
0.036\end{array}$ & $\begin{array}{l}0.000 \\
0.081\end{array}$ & $\begin{array}{l}0.258 \\
0.187\end{array}$ \\
\hline Firms & 1018 & 1018 & 754 & 754 & 219 & 219 & 427 & 427 & 567 & 567 \\
\hline Observations & 5296 & 5296 & 4235 & 4235 & 668 & 668 & 2638 & 2638 & 2260 & 2260 \\
\hline
\end{tabular}

The dependent variable is the first difference of the ratio of investment to beginning-of-period capital, $I_{i t} / K_{i, t-1}$. The regressors are the first differences of tax-adjusted Tobin's $Q_{i t}$, real $Q_{i t}$ constructed using I/B/E/S analysts' beginning-of-period forecasts, and the ratio of cash flow to beginning-of-period capital, $C F_{i t} / K_{i, t-1}$. Year dummies and an intercept are included (but not reported) in all regressions. Robust standard errors on coefficients are in parentheses.

The estimation period is 1988-95. The sample contains the firms with at least four years of complete Compustat and I/B/E/S data. The "dividend" and "no dividend" samples contain firms that did and did not pay dividends in the prior year. The "bond rating" and "no bond rating" samples contain firms that are rated and not rated by Standard \& Poor's at the beginning of the year.

Instrumental variables in the first panel are the period $t-2, t-3$, and $t-4$ values of $I / K$, tax-adjusted Tobin's $Q$, and $C F / K$. Instrumental variables in the second panel are the period $t-2, t-3$, and $t-4$ values of $I / K$, $C F / K$, and the ratio of sales to beginning-of-period capital, $Y / K$. The instrument sets also contain an intercept and year dummies.

The Sargan statistic is a test of the overidentifying restrictions asymptotically distributed $\chi_{(n-p)}^{2}$, where $n$ is the number of instruments and $p$ is the number of parameters. The $m_{2}$ statistic is a test for second-order serial correlation in the residuals, asymptotically distributed as $\mathrm{N}(0,1)$ under the null of no serial correlation. 
Table 4: GMM Estimates of First Differenced Investment Equations: Comparing Instrument Sets Containing Tobin's $Q$ and "Fundamental"Variables (Compustat Sample)

\begin{tabular}{|c|c|c|c|c|c|}
\hline Parameter & $\begin{array}{l}\text { All Firms } \\
\text { (1) }\end{array}$ & $\begin{array}{l}\text { Dividend } \\
\text { (2) }\end{array}$ & $\begin{array}{l}\text { No Dividend } \\
\text { (3) }\end{array}$ & $\begin{array}{c}\text { Bond Rating } \\
\text { (4) }\end{array}$ & $\begin{array}{l}\text { No Bond Rating } \\
\text { (5) }\end{array}$ \\
\hline & \multicolumn{5}{|c|}{ INSTRUMENT SET WiTH TOBIN'S $Q$} \\
\hline Tobin's $Q_{i t}$ & $\begin{array}{c}0.019 \\
(0.007)\end{array}$ & $\begin{array}{c}0.015 \\
(0.008)\end{array}$ & $\begin{array}{c}0.054 \\
(0.021)\end{array}$ & $\begin{array}{l}0.028 \\
(0.014)\end{array}$ & $\begin{array}{l}0.016 \\
(0.010)\end{array}$ \\
\hline$C F_{i t} / K_{i, t-1}$ & $\begin{array}{c}0.247 \\
(0.049)\end{array}$ & $\begin{array}{c}0.101 \\
(0.051)\end{array}$ & $\begin{array}{c}0.169 \\
(0.101)\end{array}$ & $\begin{array}{c}0.272 \\
(0.072)\end{array}$ & $\begin{array}{c}0.215 \\
(0.062)\end{array}$ \\
\hline \multirow[t]{2}{*}{$\begin{array}{l}\text { Sargan } p \text {-value } \\
m_{2} p \text {-value }\end{array}$} & $\begin{array}{l}0.000 \\
0.000\end{array}$ & $\begin{array}{l}0.000 \\
0.002\end{array}$ & $\begin{array}{l}0.000 \\
0.002\end{array}$ & $\begin{array}{l}0.004 \\
0.002\end{array}$ & $\begin{array}{l}0.000 \\
0.000\end{array}$ \\
\hline & \multicolumn{5}{|c|}{ INSTRUMENT SET WiTH “FUNDAMENTAL” VARIABLES } \\
\hline Tobin's $Q_{i t}$ & $\begin{array}{l}0.108 \\
(0.044)\end{array}$ & $\begin{array}{c}0.103 \\
(0.052)\end{array}$ & $\begin{array}{c}0.158 \\
(0.082)\end{array}$ & $\begin{array}{c}0.175 \\
(0.060)\end{array}$ & $\begin{array}{c}0.202 \\
(0.051)\end{array}$ \\
\hline$C F_{i t} / K_{i, t-1}$ & $\begin{array}{c}0.234 \\
(0.212)\end{array}$ & $\begin{array}{c}0.374 \\
(0.237)\end{array}$ & $\begin{array}{l}-0.191 \\
(0.319)\end{array}$ & $\begin{array}{c}0.095 \\
(0.157)\end{array}$ & $\begin{array}{c}0.304 \\
(0.170)\end{array}$ \\
\hline $\begin{array}{l}\text { Sargan } p \text {-value } \\
m_{2} p \text {-value }\end{array}$ & $\begin{array}{l}0.000 \\
0.000\end{array}$ & $\begin{array}{l}0.097 \\
0.133\end{array}$ & $\begin{array}{l}0.001 \\
0.467\end{array}$ & $\begin{array}{l}0.274 \\
0.018\end{array}$ & $\begin{array}{l}0.435 \\
0.005\end{array}$ \\
\hline $\begin{array}{l}\text { Firms } \\
\text { Observations }\end{array}$ & $\begin{array}{l}1361 \\
7162\end{array}$ & $\begin{array}{c}890 \\
5029\end{array}$ & $\begin{array}{c}414 \\
1383\end{array}$ & $\begin{array}{c}486 \\
2773\end{array}$ & $\begin{array}{c}847 \\
3655\end{array}$ \\
\hline
\end{tabular}

See notes to Table 3.

The sample contains the firms with at least four years of complete Compustat data. 
Table 5: GMM Estimates of First Differenced Investment Equations: Comparing Instrument Sets Containing “Fundamental” Variables and Analysts' Forecasts

\begin{tabular}{|c|c|c|c|c|c|c|c|c|c|c|}
\hline \multirow[t]{2}{*}{ Parameter } & \multicolumn{2}{|c|}{ All Firms } & \multicolumn{2}{|c|}{ Dividend } & \multicolumn{2}{|c|}{ No Dividend } & \multicolumn{2}{|c|}{ Bond Rating } & \multicolumn{2}{|c|}{ No Bond Rating } \\
\hline & (1) & (2) & (3) & (4) & (5) & (6) & (7) & (8) & $(9)$ & $(10)$ \\
\hline & \multicolumn{10}{|c|}{ INSTRUMENT SET WITH “FUNDAMENTAL” VARIABLES AND ANALYSTS' FORECASTS } \\
\hline Tobin's $Q_{i t}$ & $\begin{array}{c}0.098 \\
(0.026)\end{array}$ & - & $\begin{array}{c}0.152 \\
(0.059)\end{array}$ & - & $\begin{array}{c}0.075 \\
(0.040)\end{array}$ & - & $\begin{array}{c}0.106 \\
(0.040)\end{array}$ & - & $\begin{array}{c}0.047 \\
(0.022)\end{array}$ & - \\
\hline Real $Q_{i t}$ & - & $\begin{array}{c}0.181 \\
(0.069)\end{array}$ & - & $\begin{array}{c}0.333 \\
(0.122)\end{array}$ & - & $\begin{array}{c}0.026 \\
(0.033)\end{array}$ & - & $\begin{array}{c}0.265 \\
(0.175)\end{array}$ & - & $\begin{array}{c}0.121 \\
(0.052)\end{array}$ \\
\hline$C F_{i t} / K_{i, t-1}$ & $\begin{array}{c}0.079 \\
(0.096)\end{array}$ & $\begin{array}{l}-0.071 \\
(0.173)\end{array}$ & $\begin{array}{c}-0.077 \\
(0.247)\end{array}$ & $\begin{array}{c}-0.500 \\
(0.388)\end{array}$ & $\begin{array}{c}0.070 \\
(0.123)\end{array}$ & $\begin{array}{c}0.052 \\
(0.085)\end{array}$ & $\begin{array}{c}-0.193 \\
(0.225)\end{array}$ & $\begin{array}{l}-0.469 \\
(0.557)\end{array}$ & $\begin{array}{c}0.036 \\
(0.080)\end{array}$ & $\begin{array}{c}-0.085 \\
(0.150)\end{array}$ \\
\hline & 0.003 & $\begin{array}{l}0.000 \\
0298\end{array}$ & 0.717 & $\begin{array}{l}0.001 \\
0.878\end{array}$ & 0.019 & 0.000 & 0.225 & 0.148 & 0.000 & 0.013 \\
\hline$m_{2} p$-value & \multicolumn{10}{|c|}{ INSTRUMENT SET With ANALYSTS' FORECASTS } \\
\hline Tobin's $Q_{i t}$ & $\begin{array}{c}0.163 \\
(0.049)\end{array}$ & - & $\begin{array}{c}0.159 \\
(0.071)\end{array}$ & - & $\begin{array}{c}0.146 \\
(0.061)\end{array}$ & - & $\begin{array}{c}0.175 \\
(0.059)\end{array}$ & - & $\begin{array}{c}0.151 \\
(0.052)\end{array}$ & - \\
\hline Real $Q_{i t}$ & - & $\begin{array}{c}0.522 \\
(0.206)\end{array}$ & - & $\begin{array}{c}0.507 \\
(0.178)\end{array}$ & - & $\begin{array}{c}0.200 \\
(0.081)\end{array}$ & - & $\begin{array}{c}0.459 \\
(0.183)\end{array}$ & - & $\begin{array}{c}0.416 \\
(0.124)\end{array}$ \\
\hline$C F_{i t} / K_{i, t-1}$ & $\begin{array}{l}-0.101 \\
(0.188)\end{array}$ & $\begin{array}{c}-0.469 \\
(0.448)\end{array}$ & $\begin{array}{c}-0.099 \\
(0.329)\end{array}$ & $\begin{array}{c}-0.974 \\
(0.563)\end{array}$ & $\begin{array}{c}0.205 \\
(0.176)\end{array}$ & $\begin{array}{c}0.016 \\
(0.140)\end{array}$ & $\begin{array}{c}-0.251 \\
(0.305)\end{array}$ & $\begin{array}{c}-0.984 \\
(0.535)\end{array}$ & $\begin{array}{c}-0.320 \\
(0.179)\end{array}$ & $\begin{array}{c}-0.531 \\
(0.288)\end{array}$ \\
\hline \multirow[t]{2}{*}{$\begin{array}{l}\text { Sargan } p \text {-value } \\
m_{2} p \text {-value }\end{array}$} & $\begin{array}{l}0.321 \\
0.094\end{array}$ & $\begin{array}{l}0.532 \\
0.333\end{array}$ & $\begin{array}{l}0.511 \\
0.425\end{array}$ & $\begin{array}{l}0.013 \\
0.408\end{array}$ & $\begin{array}{l}0.229 \\
0.181\end{array}$ & $\begin{array}{l}0.072 \\
0.354\end{array}$ & $\begin{array}{l}0.810 \\
0.577\end{array}$ & $\begin{array}{l}0.430 \\
0.025\end{array}$ & $\begin{array}{l}0.372 \\
0.093\end{array}$ & $\begin{array}{l}0.544 \\
0.078\end{array}$ \\
\hline & \multicolumn{10}{|c|}{ InSTRUMENT SET With ANALYSTS' TwO-YEAR-AHEAD AND LONG TERM GROWTH FORECASTS } \\
\hline Tobin's $Q_{i t}$ & $\begin{array}{c}0.225 \\
(0.083)\end{array}$ & - & $\begin{array}{c}0.175 \\
(0.080)\end{array}$ & - & $\begin{array}{c}0.298 \\
(0.144)\end{array}$ & - & $\begin{array}{c}0.206 \\
(0.064)\end{array}$ & - & $\begin{array}{c}0.156 \\
(0.065)\end{array}$ & - \\
\hline Real $Q_{i t}$ & - & $\begin{array}{c}0.472 \\
(0.222)\end{array}$ & - & $\begin{array}{c}0.560 \\
(0.198)\end{array}$ & - & $\begin{array}{c}0.248 \\
(0.092)\end{array}$ & - & $\begin{array}{c}0.442 \\
(0.182)\end{array}$ & - & $\begin{array}{c}0.393 \\
(0.154)\end{array}$ \\
\hline$C F_{i t} / K_{i, t-1}$ & $\begin{array}{l}-0.027 \\
(0.329)\end{array}$ & $\begin{array}{l}-0.457 \\
(0.569)\end{array}$ & $\begin{array}{l}-0.081 \\
(0.334)\end{array}$ & $\begin{array}{c}-0.855 \\
(0.626)\end{array}$ & $\begin{array}{c}0.105 \\
(0.414)\end{array}$ & $\begin{array}{c}0.016 \\
(0.160)\end{array}$ & $\begin{array}{c}-0.321 \\
(0.392)\end{array}$ & $\begin{array}{l}-0.913 \\
(0.645)\end{array}$ & $\begin{array}{l}-0.246 \\
(0.213)\end{array}$ & $\begin{array}{l}-0.455 \\
(0.386)\end{array}$ \\
\hline $\begin{array}{l}\text { Sargan } p \text {-value } \\
m_{2} p \text {-value }\end{array}$ & $\begin{array}{l}0.953 \\
0.134\end{array}$ & $\begin{array}{l}0.381 \\
0.625\end{array}$ & $\begin{array}{l}0.441 \\
0.374\end{array}$ & $\begin{array}{l}0.056 \\
0.629\end{array}$ & $\begin{array}{l}0.672 \\
0.305\end{array}$ & $\begin{array}{l}0.117 \\
0.275\end{array}$ & $\begin{array}{l}0.873 \\
0.618\end{array}$ & $\begin{array}{l}0.063 \\
0.050\end{array}$ & $\begin{array}{l}0.327 \\
0.093\end{array}$ & $\begin{array}{l}0.879 \\
0.344\end{array}$ \\
\hline $\begin{array}{l}\text { Firms } \\
\text { Observations }\end{array}$ & $\begin{array}{l}1018 \\
5296\end{array}$ & $\begin{array}{l}1018 \\
5296\end{array}$ & $\begin{array}{c}754 \\
4235\end{array}$ & $\begin{array}{c}754 \\
4235\end{array}$ & $\begin{array}{l}219 \\
668\end{array}$ & $\begin{array}{l}219 \\
668\end{array}$ & $\begin{array}{c}427 \\
2638\end{array}$ & $\begin{array}{c}427 \\
2638\end{array}$ & $\begin{array}{c}567 \\
2260\end{array}$ & $\begin{array}{c}567 \\
2260\end{array}$ \\
\hline
\end{tabular}

See notes to table 3 .

Instrumental variables in the first panel are the period $t-2, t-3$, and $t-4$ values of $I / K, C F / K, Y / K$, the ratios of the analysts' forecasts of one-year-ahead and two-year-ahead earnings to beginning-of-period capital, and the long-term growth forecasts. In the second panel, the lags of $C F / K$ and $Y / K$ are omitted from the instrument set. In the third panel, the one-year-ahead forecasts are omitted from the instrument set in the second panel. The instrument sets also contain an intercept and year dummies. 
Table 6: GMM Estimates of First Differenced Investment Equations: Alternative Definitions of Real $Q$

\begin{tabular}{|c|c|c|c|c|c|c|c|c|c|c|}
\hline \multirow[t]{2}{*}{ Parameter } & \multicolumn{2}{|c|}{ All Firms } & \multicolumn{2}{|c|}{ Dividend } & \multicolumn{2}{|c|}{ No Dividend } & \multicolumn{2}{|c|}{ Bond Rating } & \multicolumn{2}{|c|}{ No Bond Rating } \\
\hline & (1) & (2) & (3) & (4) & (5) & (6) & (7) & (8) & (9) & (10) \\
\hline Long-Run Real $Q_{i t}$ & $\begin{array}{c}0.689 \\
(0.271)\end{array}$ & - & $\begin{array}{c}0.444 \\
(0.212)\end{array}$ & - & $\begin{array}{c}0.248 \\
(0.100)\end{array}$ & - & $\begin{array}{c}0.414 \\
(0.187)\end{array}$ & - & $\begin{array}{c}0.500 \\
(0.151)\end{array}$ & - \\
\hline Terminal-Value Real $Q_{i t}$ & - & $\begin{array}{l}0.398 \\
(0.166)\end{array}$ & - & $\begin{array}{c}0.261 \\
(0.119)\end{array}$ & - & $\begin{array}{c}0.137 \\
(0.053)\end{array}$ & - & $\begin{array}{c}0.193 \\
(0.095)\end{array}$ & - & $\begin{array}{c}0.261 \\
(0.080)\end{array}$ \\
\hline$C F_{i t} / K_{i, t-1}$ & $\begin{array}{l}-0.480 \\
(0.454)\end{array}$ & $\begin{array}{l}-0.645 \\
(0.554)\end{array}$ & $\begin{array}{l}-0.506 \\
(0.485)\end{array}$ & $\begin{array}{l}-0.627 \\
(0.520)\end{array}$ & $\begin{array}{c}0.019 \\
(0.140)\end{array}$ & $\begin{array}{l}-0.009 \\
(0.143)\end{array}$ & $\begin{array}{l}-0.593 \\
(0.688)\end{array}$ & $\begin{array}{l}-0.498 \\
(0.710)\end{array}$ & $\begin{array}{l}-0.479 \\
(0.263)\end{array}$ & $\begin{array}{l}-0.547 \\
(0.289)\end{array}$ \\
\hline $\begin{array}{l}\text { Sargan } p \text {-value } \\
m_{2} p \text {-value }\end{array}$ & $\begin{array}{l}0.606 \\
0.356\end{array}$ & $\begin{array}{l}0.687 \\
0.398\end{array}$ & $\begin{array}{l}0.000 \\
0.890\end{array}$ & $\begin{array}{l}0.001 \\
0.763\end{array}$ & $\begin{array}{l}0.062 \\
0.372\end{array}$ & $\begin{array}{l}0.095 \\
0.301\end{array}$ & $\begin{array}{l}0.220 \\
0.061\end{array}$ & $\begin{array}{l}0.171 \\
0.064\end{array}$ & $\begin{array}{l}0.502 \\
0.114\end{array}$ & $\begin{array}{l}0.422 \\
0.138\end{array}$ \\
\hline Firm & 1018 & 1018 & 754 & 75 & 219 & 21 & 42 & 42 & 567 & 567 \\
\hline Observations & 5296 & 5296 & 4235 & 4235 & 668 & 668 & 2638 & 2638 & 2260 & 2260 \\
\hline
\end{tabular}

See notes to table 3 .

Long-run real $Q_{i t}$ is constructed using analysts' forecasts of two-year-ahead earnings and long-term growth forecasts. It excludes the one-year-ahead forecasts. Terminal-value real $Q_{i t}$ is constructed by adding a terminal value calculation to real $Q_{i t}$.

Instrumental variables are the period $t-2, t-3$, and $t-4$ values of $I / K$, the ratios of the analysts' forecasts of one-year-ahead and two-year-ahead earnings to beginning-of-period capital, and the long-term growth forecasts. The instrument set also contain an intercept and year dummies. 
Figure 1: Kernel Regression Smoother of Investment as a Function of Cash Flow

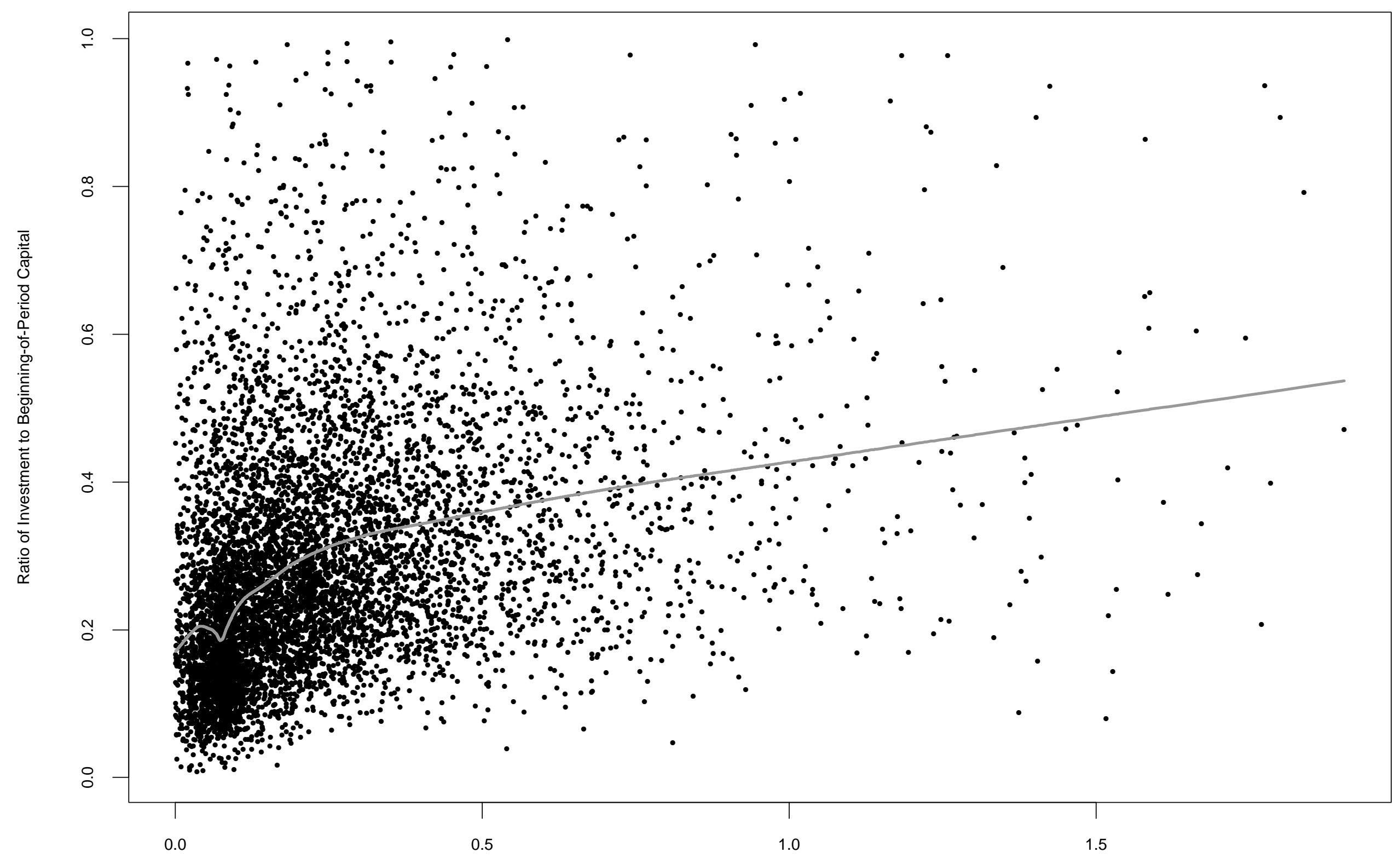

Ratio of Lagged Cash Flow to Beginning-of-Period Capital 
Figure 2: Kernel Regression Smoother of Real $Q$ as a Function of Cash Flow

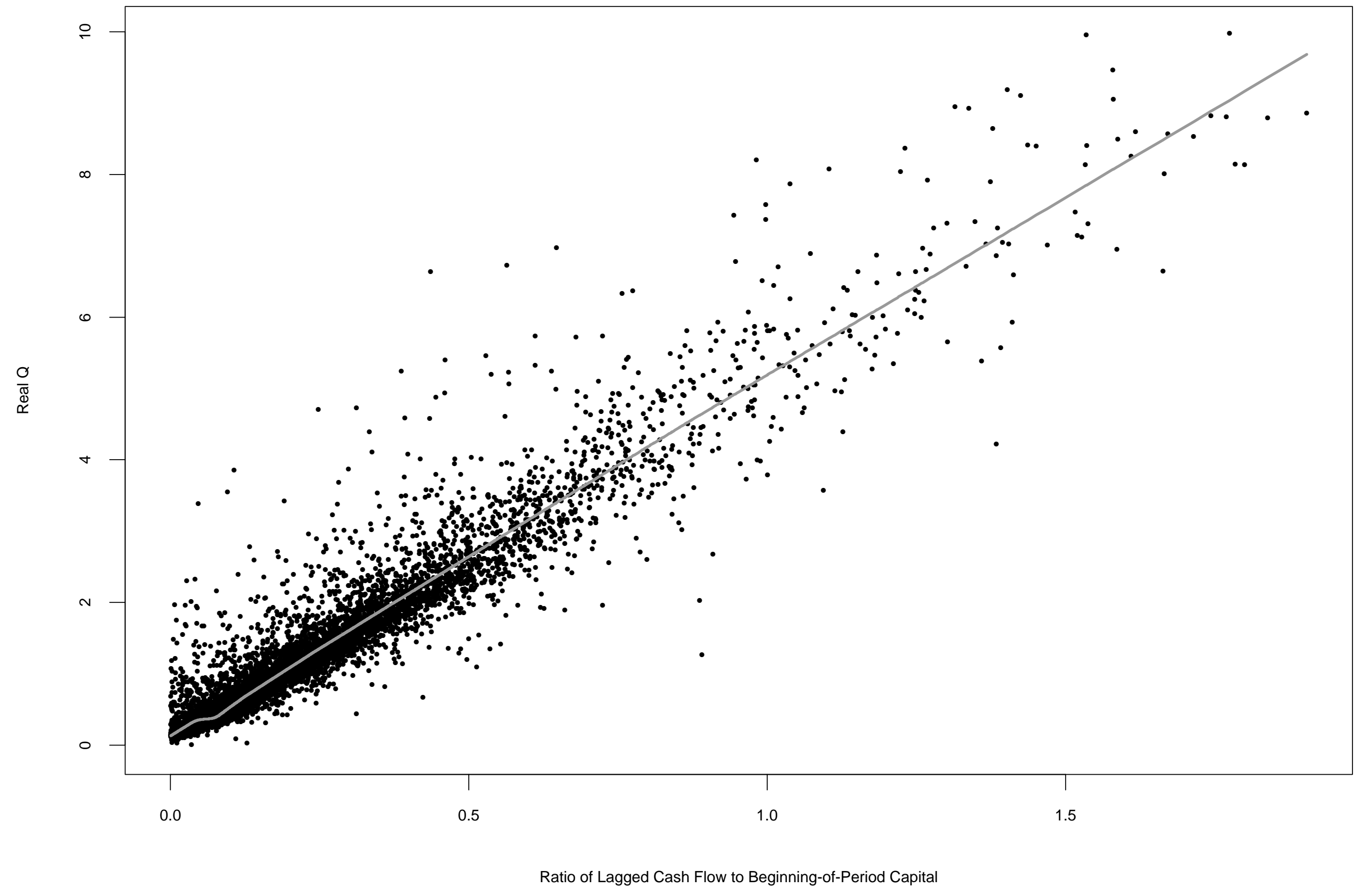


Figure 3: Kernel Regression Smoother of Investment as a Function of Cash Flow Controlling for Real Q

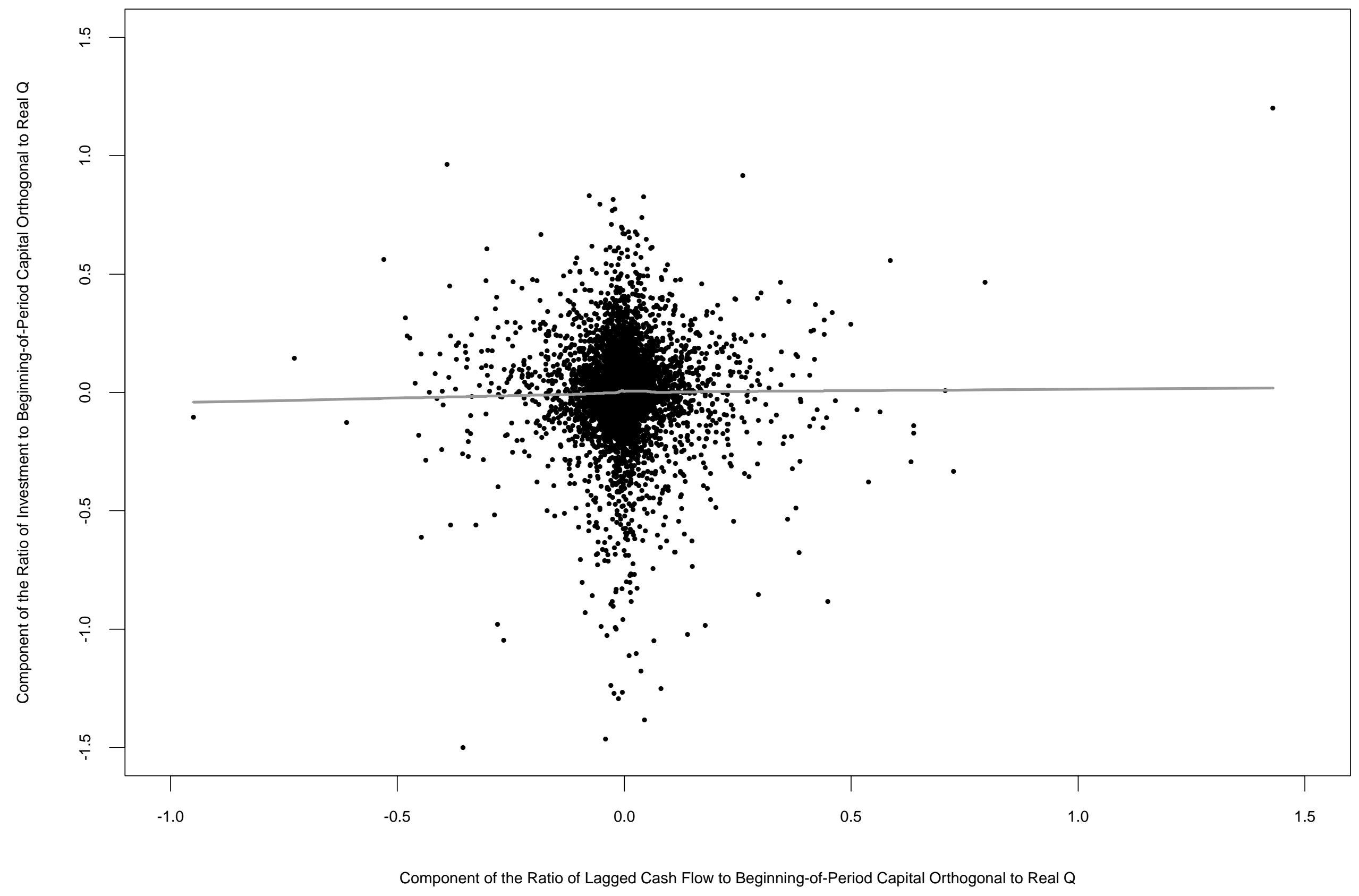


Figure 4: Kernel Regression Smoother of Investment as a Function of Real Q

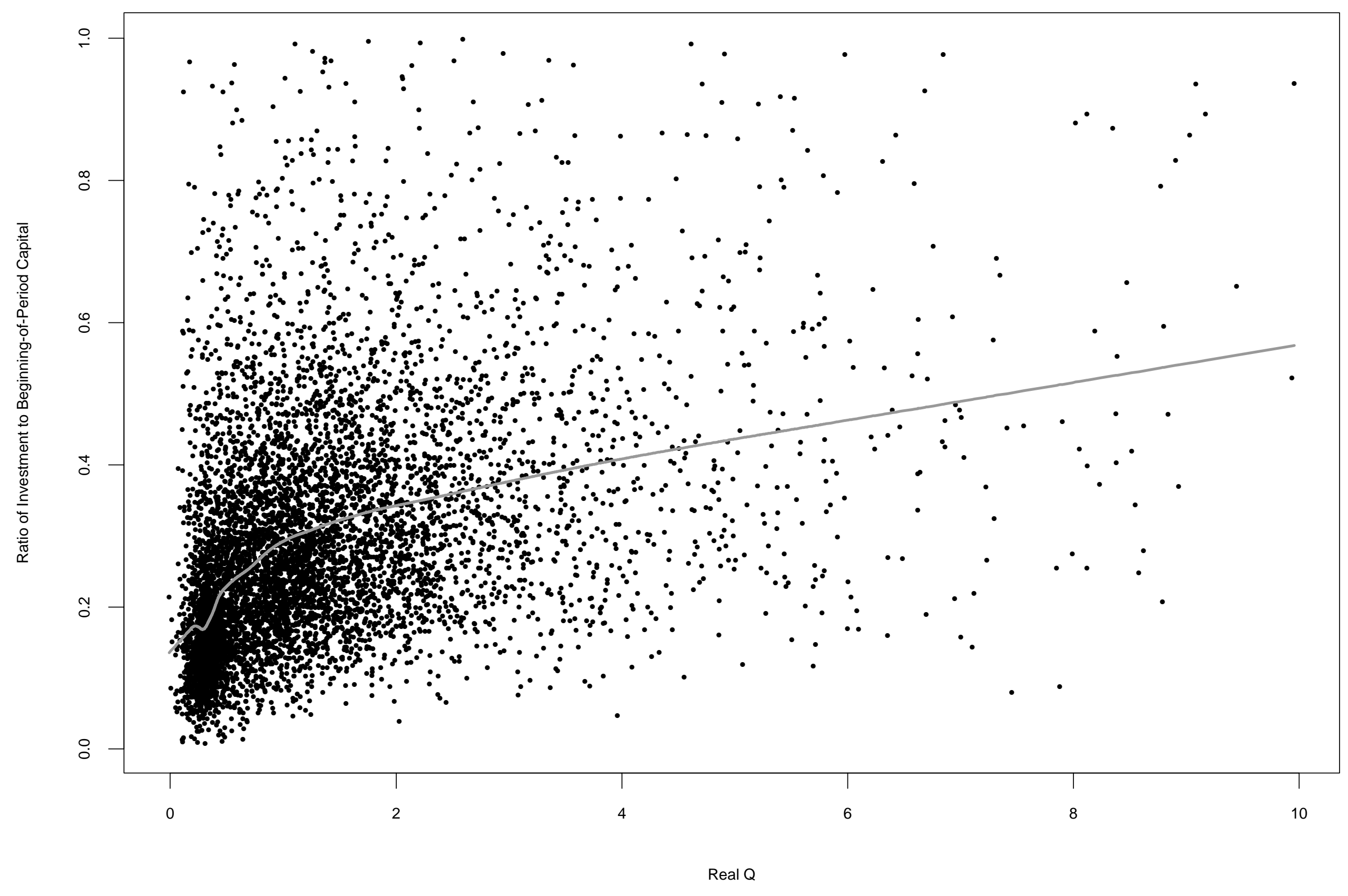



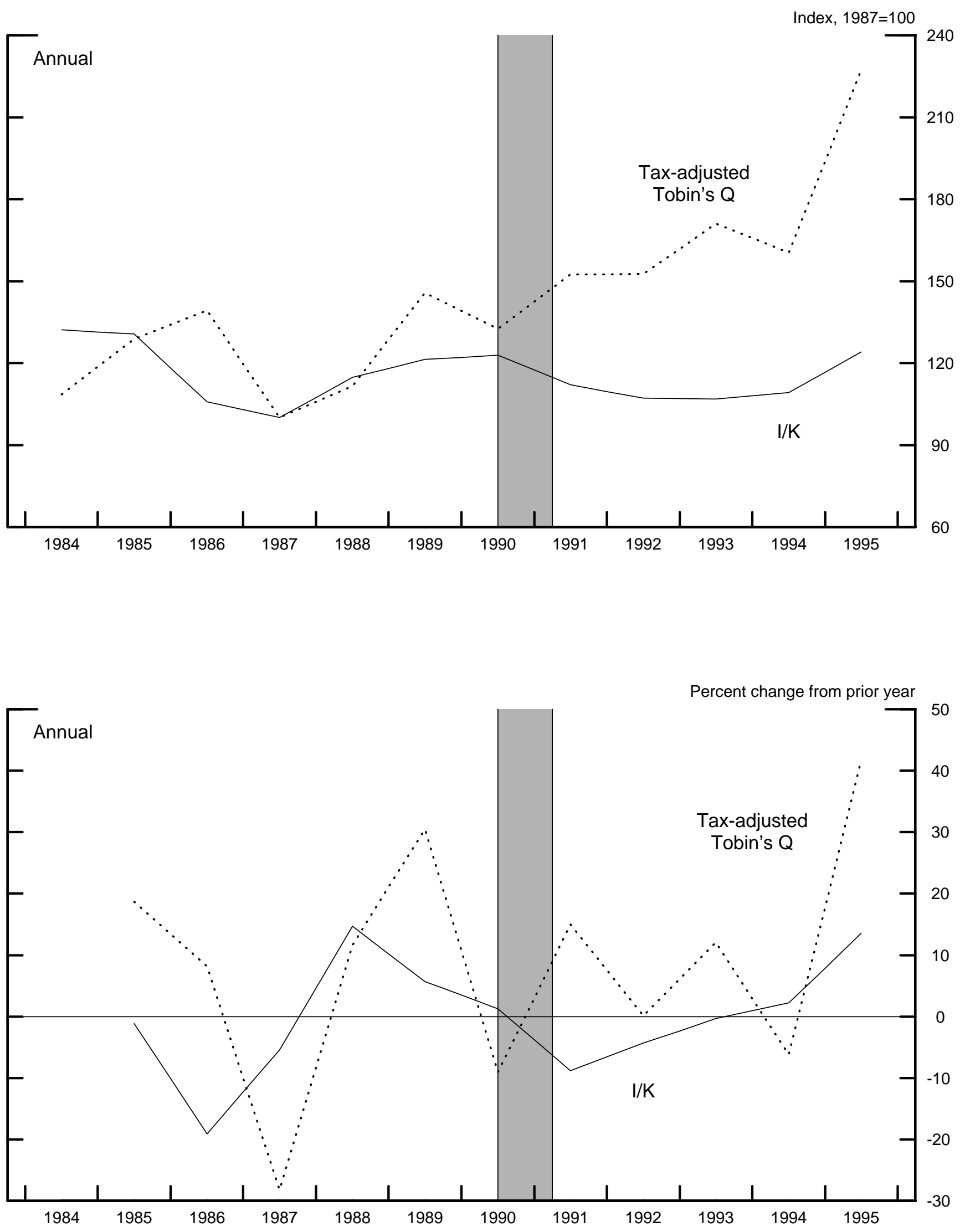

Note. Aggregate $\mathrm{I} / \mathrm{K}$ and tax-adjusted Tobin's $\mathrm{Q}$ are constructed by the authors as a weighted average of firm-level Compustat variables, with each firm's weight equal to its share of aggregate beginning-of-year capital stock. Shading indicates 1990-91 recession. 

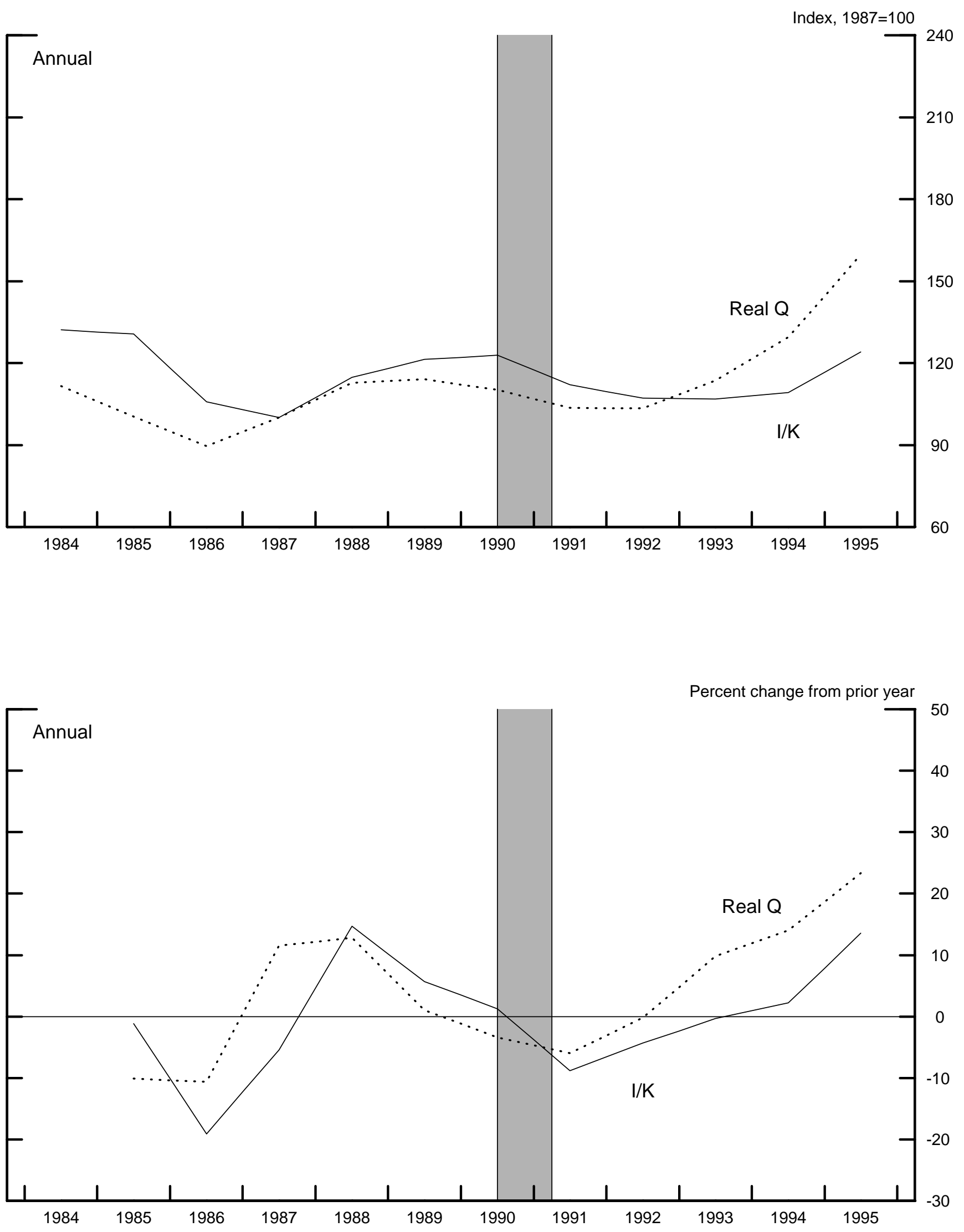

Note. Aggregate $\mathrm{I} / \mathrm{K}$ and real $\mathrm{Q}$ are constructed by the authors as a weighted average of firm-level I/B/E/S and Compustat variables, with each firm's weight equal to its share of aggregate beginning-of-year capital stock. Shading indicates 1990-91 recession. 